This item was submitted to Loughborough's Research Repository by the author.

Items in Figshare are protected by copyright, with all rights reserved, unless otherwise indicated.

\title{
Research travel and disciplinary identities in the University of Cambridge, 1885-1955
}

PLEASE CITE THE PUBLISHED VERSION

http://dx.doi.org/10.1017/S000708741200074X

\section{PUBLISHER}

Cambridge University Press / @ British Society for the History of Science

\section{VERSION}

AM (Accepted Manuscript)

\section{PUBLISHER STATEMENT}

This work is made available according to the conditions of the Creative Commons Attribution-NonCommercialNoDerivatives 4.0 International (CC BY-NC-ND 4.0) licence. Full details of this licence are available at: https://creativecommons.org/licenses/by-nc-nd/4.0/

\section{LICENCE}

CC BY-NC-ND 4.0

\section{REPOSITORY RECORD}

Heffernan, Michael, and Heike Jons. 2019. "Research Travel and Disciplinary Identities in the University of Cambridge, 1885-1955”. figshare. https://hdl.handle.net/2134/16189. 


\section{Research travel and disciplinary identities in the University of}

\section{Cambridge, 1885-1955}

Michael Heffernan and Heike Jöns

\section{Abstract}

This article considers the role of overseas academic travel in the development of the modern research university, with particular reference to the University of Cambridge from the 1880 s to the 1950 s. The Cambridge academic community, relatively sedentary at the beginning of this period, became progressively more mobile and globalised through the early twentieth century, facilitated by regular research sabbaticals. The culture of research travel diffused at varying rates, and with differing consequences, across the arts and humanities and the field, laboratory and theoretical sciences, re-shaping disciplinary identities and practices in the process. The nature of research travel also changed as the genteel scholarly excursion was replaced by the purposeful, output-orientated expedition.

Key words travel, knowledge, science, geography, University of Cambridge 


\section{Introduction}

On $8^{\text {th }}$ October 1918, Arthur Eddington, Plumian Professor of Astronomy and Experimental Philosophy at Cambridge and Director of the university's Observatory, wrote a letter to his colleague W. L. Mollison, a well-known mathematician, Master of Clare College, and a member of the university's General Board. The letter outlined Eddington's latest attempts to verify by experiment Einstein's general theory of relativity, a quest that had come to dominate his research and on which he had staked his considerable scientific reputation. Eddington requested leave of absence for the subsequent Lent and Easter terms (January to June 1919) to lead an expedition, sponsored jointly by the Royal Society and the Royal Astronomical Society, to Principe Island in the Gulf of Guinea. The objective was to measure the deflection of light by gravitation during a total solar eclipse, due to occur in the region on $29^{\text {th }}$ May. Similar measurements were to be taken at the same time by a second expedition to Sobral in Brazil, led by Andrew Crommelin of the Royal Observatory in Greenwich. The 1919 eclipse was 'the most favourable opportunity ... of our lifetime' to carry out these observations, Eddington claimed, and the results would be 'a matter of rather fundamental importance in connection with recent physical theories' ${ }^{1}$

The General Board unanimously accepted Eddington's proposal a few days later, paving the way for one of the most important episodes in the history of modern physics, one that underlines the early twentieth century conviction that abstract, cerebral and conceptual theoretical reasoning ultimately required the 'ground truth' of specific measurement 'in the field'. Eddington's results, published shortly after the expeditions, offered compelling proof of Einstein's challenge to 
Newtonian physics and were extensively discussed in these terms in the news media. ${ }^{2}$ Although these results have recently been questioned, the 1919 expeditions undeniably facilitated the diffusion of Einstein's theory into the English-speaking world from which it had been partially excluded during World War One. ${ }^{3}$

Eddington's 1919 experiences are an appropriate starting point for this essay for two reasons. First, the success of his expedition changed prevailing attitudes in Cambridge, and perhaps more generally in British higher education, towards extended periods of overseas research leave. Eddington's 'sabbatical' arguably launched the current system of research leave in Cambridge, earlier requests having been greeted with scepticism or even outright hostility. ${ }^{4}$ Second, Eddington's costly expedition draws attention to the complex motivations and controversial consequences of overseas research travel, and raises the two questions that lie at the heart of the present inquiry: What were the patterns and trends in the mobility of modern university academics during the twentieth century? And in what ways, if at all, did research travel influence the development of scientific theory and practice?

These are scarcely unheralded inquiries, though they have most frequently been examined in relation to the more challenging, time-consuming and costly longdistance voyages of pre-twentieth century science. Although there was vigorous debate within early modern science about the value of travel and the relative merits of knowledge acquired through sedentary labour in the laboratory and direct observation in the field, the constitutive significance of mobility on the development of scientific theory and practice in these earlier periods has been generally acknowledged by historians. ${ }^{5}$ In the vastly more mobile twentieth century, however, 
when long-distance travel required less time and effort, the movements of scientists around the globe have been subjected to less critical scrutiny. ${ }^{6}$ While recent work on the geographies of the scientific process has explored related questions, the emphasis has been on location and environment rather than movement and mobility. ${ }^{7}$ The inducements of sociologists of modern science to 'follow' scientists and engineers has likewise implied intellectual journeys through society rather than geographical voyages across space. ${ }^{8}$

Drawing on unpublished archival material from the University of Cambridge, this essay demonstrates that science and scholarship was inextricably linked to the movement of people, resources and ideas throughout the twentieth century, the era when science became the preserve of a globalised, hyper-mobile, university elite whose power and prestige rested in part on their capacity to travel long distances in connection with their research. ${ }^{9}$ This transformation took place gradually, facilitated by the introduction of new programmes of sabbatical leave, initially in US universities and subsequently in leading British, Australian and Canadian institutions of higher learning. ${ }^{10}$ Although there is abundant anecdotal evidence attesting to the creative importance of periods of uninterrupted research leave, the sabbatical has rarely been examined in a systematic fashion. ${ }^{11}$

By mapping where Cambridge academics conducted their research, this analysis reveals the global geographies of knowledge production that influenced the university's scientific and scholarly research cultures. More specifically, the investigation suggests that the diffusion of a new culture of overseas travel within Cambridge was not a uniform process but impacted variously on different disciplines 
and research practices in the arts and humanities as well as in the social, natural and technical sciences.

This essay proceeds in three parts. The first part positions our study in relation to the existing literature and discusses the archival sources on which the analysis rests. The second part outlines how travel helped to transform Cambridge into a modern research university. The third part compares field-specific travel cultures on a global scale and suggests that venturing out into the world and practising research in the same places profoundly shaped the evolution of modern disciplines in the first half of the twentieth century.

\section{Situating research travel}

Historians, geographers, ethnographers and sociologists of science have mapped the geographies of knowledge production and circulation using various methodologies. They have, for example, considered sites of study, work places, correspondence networks, and the career trajectories of academics. ${ }^{12}$ This study considers the wider networks that have shaped knowledge production in the modern research university by examining the places where university research was conducted, the linkages and connections travellers established between the university and other sites of study, and the difference these networks made to the science and scholarship carried out by academics. ${ }^{13}$

Academic travel is defined here as those temporary and mostly circular journeys undertaken for research, to present a lecture or seminar, to attend a conference, or simply to network with colleagues. These forms of mobility have the capacity to transform the ideas, practices and values of both the travelling 
researchers and their hosting colleagues. We analyse three dimensions of academic travel that can both motivate these journeys and produce related outcomes, namely intellectual resources such as scientific and cultural knowledge, social interactions with peers and others, and material aspects, including research sites, objects and infrastructure. $^{14}$

Travel for research and learning can be regarded as a specific form of academic travel, but in the eighteenth and nineteenth centuries, research-related travel occurred outside of the university, mainly in the form of educational travel and scientific exploration. ${ }^{15}$ The latter built upon previous discoveries that began to pursue a more systematic scientific agenda when James Cook first entered the Pacific in 1769, a moment that David Stoddart famously identified as the birth of modern scientific geography. ${ }^{16}$ These oceanic explorations were complemented by early nineteenth century terrestrial explorations, especially into Africa and subsequently to central Asia, the Polar Regions and the Himalayas. ${ }^{17}$ Scientific exploration was sponsored directly by the state, initially through naval and commercial ministries and later by specialised scientific societies such as the Royal Geographical Society founded in Britain in $1830 .^{18}$

Educational travel emerged in the context of the Grand Tour, an extended journey through the cultural centres of Europe that became an obligatory educational experience for young male aristocrats in the seventeenth and eighteenth centuries before taking their place in society. ${ }^{19}$ Touring the European continent began to flourish when the new wealthy middle classes of the early nineteenth century were willing and able to invest their own money to acquire the cultural prestige and authority that travel into the heartlands of classic antiquity had 
brought to eighteenth century gentlemen. This middle-class educational tourism, especially to the eastern Mediterranean, was facilitated by new rail and steamboat lines and became eventually organised by specialised tourist agencies such as the one Thomas Cook run in Leicester since the 1840s. In 1855, when Cook organised his first overseas conducted tour, 'the age of the Grand Tour was over and the age of tourism had arrived' ${ }^{20}$

Neither of these earlier forms of research travel - educational tourism or scientific exploration - was linked to the universities. Since the foundation of universities in the European middle ages, academic travel had concentrated on career- and teaching-related moves as epitomized by the itineraries of late medieval and early modern scholars such as Erasmus of Rotterdam. ${ }^{21}$ The main objective of students' and scholars' travels between cosmopolitan seats of learning, in which Latin served as the lingua franca, was the transmission and preservation of predominantly Greek and Arab scholarship. ${ }^{22}$ Peter Burke argued that since the twelfth century, when universities began to replace monasteries as the main centres of learning in Europe, new ideas created by creative, often marginal individuals and groups were primarily discussed in new venues and institutions that became the formal, mainstream and conservative organizations of the next generation. ${ }^{23}$ Accordingly, the humanist movement of the sixteenth, the scientific revolution of the seventeenth, and the enlightenment of the eighteenth century produced new institutions that became the seats for humanist thinking, scientific practice and research work respectively. ${ }^{24}$ It was only in the nineteenth century that the emerging research universities superseded academies and scientific societies as the major 
centres for modern science and scholarship, which raises the question about the role that travel played in this process. ${ }^{25}$

Recent work in the history and geography of science has documented the journeys of well-known explorers and scientific travellers such as James Cook, Joseph Banks, Alexander von Humboldt, and David Livingstone, and has also begun to examine wider cultures and hidden histories of exploration with an emphasis on the eighteenth and nineteenth centuries. ${ }^{26}$ A common feature of many of these biographical studies is their tracing of travellers' lives through the places they lived in. Aiming to complement this prevailing perspective, we will take a more systematic, structural and analytical approach when examining how travel emerged in the modern research university. Our approach is more systematic because it analyses the recorded travels of all academics working in one university over seven decades; it is structural because it compares travel cultures in different academic fields that reveal a variety of central places in the global flows of knowledge; and it is analytical as it relates the identified patterns to the changing organisation of the University of Cambridge and to wider economic and social developments.

By focussing on one academic institution, we also aim to develop those approaches that examine academic travel from the perspective of institutional nodes rather than nation states. ${ }^{27}$ Considering all recorded travels in one institution specifically allows for a rare comparative perspective on disciplinary cultures of research and travel, including the natural, technical and social sciences as well as the often neglected arts and humanities (hereafter humanities). ${ }^{28} \mathrm{~A}$ useful framework for understanding of how geographical imaginations have contributed to the formation of field-specific intellectual landscapes on a global scale was suggested by 
Derek Gregory. ${ }^{29}$ Drawing upon Edward Said's work, he argued that the spaces of knowledge are shaped by 'a double geography' of 'a hierarchy of spaces of knowledge production' in which some locations are regarded as more central than others and 'a hierarchy of sites of study in which some places are valorised as canonical or exotic, as exemplary sites of consuming interest, whereas others are marginalized as merely other, less interesting or less instructive instances of more general conditions that are better exemplified elsewhere'.$^{30}$ This double geography of obligatory passage points ${ }^{31}$ and popular sites of study has not only differed between disciplines and their sub-specialisms but also changed over time and space, thus contributing to complex global geographies of different research practices. In this essay, we argue that in our period of interest, the late nineteenth and early twentieth centuries, geographical imaginations about field-specific research landscapes and their global hotspots only began to take shape through the emergence of travel as the crucial research technique in most if not all evolving disciplines. $^{32}$

Drawing upon recent work in science studies, history of science and geography of science, our study presents the first systematic analysis of university archives to recreate the geography of research travel over seven decades. ${ }^{33}$ We have three objectives that are first, to comment on the role of travel for the development of professionalised research in the modern university; second, to illustrate the globalization of science and scholarship in the first half of the twentieth century through the emergence of highly mobile researchers; and third, to identify the impact of distinctive travel cultures on knowledge production in different disciplines. 
The study is based on previously unused materials from the Cambridge University Archives, specifically the applications for leave of absence by academics employed by the university, as they are recorded in the minute books of the General Board of Studies (the General Board of the Faculties after 1926) for the academic years $1885 / 86$ to $1954 / 55$. The application process became increasingly formalised from the 1880 s to the 1950 s, but most applications were based on a letter to the Secretary of the General Board that outlined the reasons for the planned leave and briefly described the intended research. From the late 1920s, most applicants had already received consent from their Head of Department or the Faculty Board so that the General Board was called on to approve arrangements agreed in the relevant departments and faculties. ${ }^{34}$

The archival records also include some of the original application letters, which were complemented by documents surviving in personal files and by biographical details taken from the Oxford Dictionary of National Biography. It is important to note that Cambridge academics had to apply for leave of absence during full term time but remained free to travel during vacations. This study thus captures not all academic travel from Cambridge but those travels during full term time that exceeded the residence requirements. Most importantly, this includes academic leaves of one to three terms, which enables us to trace the development of the research sabbatical in different disciplines. ${ }^{35}$ Despite the limitations of the archival data, it provides unique insights into the history and global geographies of academic travel that are difficult to access otherwise. ${ }^{36}$ 


\section{The emergence of a modern research university}

The idea of the modern research university was originally based on the successful integration of research and teaching at German universities. First outlined by Wilhelm von Humboldt with the foundation of Berlin University in 1810, the concept of the unity of research and teaching, or, in German, die Einheit von Forschung und Lehre, began to spread across the globe in the nineteenth century. ${ }^{37}$ In 1876 , John Hopkins University in Baltimore was founded as the first US research university with a graduate school, an American innovation derived from an idealized German role model. ${ }^{38}$ This prompted the development of graduate programmes at several universities in the United States that soon were comparable to those in the German system. ${ }^{39}$ Up to that point, doctoral training had required an extended stay in Germany so that the establishment of research universities in the United States notably changed the international flows of students and academics. ${ }^{40}$

These developments did not go unnoticed in Britain, where the ancient universities of Oxford and Cambridge had long resisted innovations from the continent and largely remained finishing schools for the clergy throughout the nineteenth century. ${ }^{41}$ Even in $1872 / 73$, Robert Phelps, the Master of Sidney Sussex in Cambridge, accused 'the reformers of drawing their inspiration from German universities', arguing that 'the university's only function was to conduct examinations, and that all teaching, including the support of laboratories, could be managed by the colleges'. ${ }^{42}$ In the context of an increasing pressure for modernization through the improved German university model in the thriving US research universities, the motto that every British university of importance 'must have facilities for science' began to guide university policies only in the $1880 \mathrm{s.}^{43}$ 
The transformation of the University of Cambridge from an ancient centre of learning into a modern research university gradually proceeded through three comprehensive university reforms that implemented recommendations of the Royal Commissions on Oxford and Cambridge launched in 1852, 1872, and 1919. The creation of a research environment similar to the situation in German universities was hesitantly pursued through the opening of the Cavendish Laboratory in 1874 and the provision of a doctorate of science $(S c D)$ and a doctorate of letters (LittD) in 1882 , but these degrees were awarded on the grounds of past achievements and thus pre-dated PhDs earned by research that were introduced in Cambridge in 1919. ${ }^{44}$ A new system of college taxation, recommended by the Royal Commission of 1872, and large private endowments enabled further significant investments in new posts and facilities in the sciences during the late nineteenth century. ${ }^{45}$

The second major university reform, implemented with the new University Statues in 1882 , contributed to the professionalization of university life by providing the first regulations on residence requirements for professors and readers during full term time. Coming into effect at the beginning of the academic year 1885/86, professors and readers were now obliged to apply to the General Board for leave of absence during those periods that exceeded the strictly defined rules of residence. ${ }^{46}$ These new regulations aimed to increase the availability of professors and readers for students and colleagues and had no significant effect on research travel. The records show that in the four decades from $1885 / 86$ to $1924 / 25$, the eve of the next university reform, the General Board granted on average only 2.1 academic leaves per year, and no more than nine in any one year, although the number of professors 
alone had risen from 39 in 1885/86 to 58 in 1924/25. Over these forty years, only 20 of 84 academic leaves were dedicated to research (24 per cent). ${ }^{47}$

The emphasis on research in the university was significantly strengthened through the third university reform. Most importantly, the concept of the 'research leave', or 'sabbatical leave', was introduced at Cambridge in 1926. Known from US universities since 1880, when Harvard University established the first system of research leave, this innovation, involving the entitlement to one term without teaching and administrative duties for every six terms of service (or every seventh year off), applied to all Cambridge University Teaching Officers. ${ }^{48}$ Based on a new leave of absence fund, research leave was granted with full stipend if all other duties in Cambridge were effectively given up. Occasionally, host universities and institutions such as the Rockefeller Foundation, the Leverhulme Trust and the Nuffield Foundation contributed to travelling expenses, but at least 80 per cent of all research leaves were fully university funded. ${ }^{49}$

The institutionalization of the research leave led to a qualitative difference in the number of granted academic leaves per year, which underlines the close association between the growing significance of research and study leave (Figure 1). About three quarters of all granted academic leaves involved travelling abroad so that the history of academic leave is basically a history of academic travel.

[Figure 1 about here]

Compared to German and American institutions, British universities identified the need for developing a research culture rather belatedly. In the case of 
Cambridge, the university administration abruptly changed the cultures of science and scholarship in the late 1920s by introducing the research leave scheme and thus making travelling the key research technique. While there is no published information available about the establishment of sabbatical schemes in other British universities, anecdotal and archival evidence from Oxford and Cambridge suggests that Cambridge set an early precedent in Britain. Cambridge scholars referred to the example of US universities when discussing regulations and applications for research leave, while the University of Oxford implemented formal regulations only in 1948 and repeatedly cited the Cambridge policies as their role model when designing a comparable sabbatical leave scheme in $1955 .^{50}$

The introduction of regular research leave in the University of Cambridge had direct implications for the travel behaviour of Cambridge academics as most of the few recorded academic leaves in the late nineteenth and early twentieth centuries aimed at lecturing abroad. It was only after the university reform in 1926 that the purpose of about half of all granted academic leaves was either research and travelling (with a recorded purpose and destination) or the unspecified research leave (without a recorded purpose and destination; see Figure 2a). Therefore, we argue that the introduction of the research leave not only contributed to the professionalization of research in the ancient university but was pivotal to Cambridge's transformation into a modern research university.

[Figure 2 about here] 


\section{Research travel and the formation of modern disciplines}

The increase in systematic travel from the University of Cambridge was linked to the development of distinctive travel cultures. By travel cultures we mean a 'variety of practices at work in the production and consumption of voyages and travels' aiming at the creation and dissemination of academic knowledge. ${ }^{51}$ These travel cultures included typical material, social, literary, bodily and reproductive practices that were implicated in different types of academic work and shaped not only the global geographies of academic travel but also disciplinary identities. ${ }^{52}$

A comparison between disciplines shows that motivations for travel other than research played very different roles. Lecturing, for example, was particularly frequent in the historical and philosophical sciences, while keeping up-to-date with the latest research on conferences was most important in the collaborative and increasingly competitive physical and biological sciences (Figure 2b). The comparative perspective also suggests that a variety of academic practices were closely related to research. For example, visiting appointments that were mainly held in the United States were most frequent in mathematics and the social sciences and often linked to both research and teaching. Consultancy work, featuring prominently in the agricultural and social sciences, often directly informed research in these applied fields of inquiry, whereas invitations to lectures and conferences were often used to embark on research-related information tours, especially when targeting the well-equipped laboratories and libraries in the United States. The archival evidence suggests that most unspecified research leaves, which were prominent in fields dominated by individual scholarship, were spent in Cambridge with the aims of uninterrupted research or writing a book. Keeping this overlap of 
research and other academic practices in mind, the main focus of the following analysis will be on 366 academic leaves for research and travelling that were primarily devoted to the production of new knowledge. These research leaves accounted for 35 per cent of all recorded academic leaves from Cambridge in the period of interest and matched their spectrum of disciplines (Figure 2b). ${ }^{53}$

The structure of disciplines discussed in this essay largely results from the existing departmental classifications at the time, but it is important to note that this disciplinary order was constantly in flux and that some departments were only founded in the 1920 s or even much later than that. ${ }^{54}$ In the following, we aim to flesh out how travel not only shaped disciplinary identities but constitutively brought them into being by gradually enrolling scientists and scholars from different fields into the new travel paradigm, a process that itself transformed how and where research was conducted (Table 1$)$.

[Table 1 about here]

Polite learning

The first official research leave at the University of Cambridge was granted in March 1886 to Sir Roland Knyvet Wilson, Reader in Indian Law since 1887 , for visiting India and obtaining knowledge of the practical working of Indian Law. ${ }^{55}$ Up to World War One, research leaves of Cambridge academics concentrated on the humanities (Figure 3a). Whether Edward Granville Browne, who had been appointed university lecturer in Persian in 1888, aimed to use two months of travel for research in Cyprus and Syria, or Solomon Schechter, Reader in Talmudic since 1892, planned to examine 
Hebrew manuscripts in Italian libraries, it were a few scholars who reached out from Cambridge to study the cultures, archives and sites about which they wrote and taught. $^{56}$

[Figure 3 about here]

Modern research travel in Cambridge thus originated from a universityfunded continuation of the educational tourism of more or less amateur scholars, linguists, archaeologists and classicists, who had previously spent either their own money or supporting funds from government research councils for visiting the places of interest to their studies. ${ }^{57}$ These places were mainly to be found in the classical arenas of Mediterranean Europe as exemplified by Cambridge scholars who contributed to the contemporary cultural production of European history and heritage by studying libraries, museums and sites in Italy, Greece, Cyprus, Turkey, Syria and Egypt. ${ }^{58}$

The highly diverse research practices in language and cultural studies, including fields such as Anglo-Saxon, Assyriology, Slavonic studies, classics, archaeology and the modern languages, were all characterised by close ties to a particular region, place or site of interest that required extended stays for acquiring language skills and cultural knowledge (Figure 4a). This is emphasized in a letter by Edward Granville Browne, the newly elected Sir Thomas Adams's Professor of Arabic (1902), who stressed the expected benefits of a planned research leave in Egypt during the Lent Term of 1903 for himself and his students: 
I am anxious ... to spend some time in Egypt, with the double object of improving my knowledge of Arabic at Cairo which still continues to be the chief centre of the old Mohammadan learning, and also of endeavouring to obtain openings for some of our students who may be able to acquire a competent knowledge of Arabic. ... The study can never flourish as it ought here. ${ }^{59}$

Five decades later, studying the language and documents of a particular culture remained an important reason for extended research leaves abroad, but in an increasingly professionalised research environment the aim was now to produce specific published outputs. This is best expressed by Donald Lawrence Keene, Lecturer in Japanese and Korean at Cambridge (1949-55) and later renowned Professor of Japanese Literature and Culture at Columbia University, who was keen to spend the academic year 1953/54 in Japan:

The object of my research is mainly to study the work of the Japanese poet Basho, something that can only be done properly in Japan owing to the large amount of unpublished manuscripts. I should also aim to brush up my spoken Japanese which has had comparatively little practice since I was an interpreter during the war. My research work on Basho would bring me in close contact with the main Japanese universities and scholars, and I should certainly spend much of my time studying in the chief libraries of Japan. I have already spent two years of preliminary work on the writings of Basho and have translated several of his chief writings. It is my hope to publish a book on my return, embodying the results of my studies. ${ }^{60}$ 
From the 1880 s to the 1950 s, the cultures of polite learning that spearheaded the emergence of institutionalised travel in the University of Cambridge had been transformed under the influence of new travel cultures that contributed to the evolution of scientific research. As the main outcome of this process, humanistic knowledge production became more targeted and output-orientated. Improved transportation and a growing international outlook of university-based scholarship also widened the geographical reach of polite learning to include Pakistan, India, China and Japan in the post-war decade.

[Figure 4 about here]

Social environments

New travel cultures in different areas of research gradually emerged in historical and philosophical studies as well as in a range of social, economic and political inquiries that constituted the disciplinary cores of law, sociology, economics, politics and anthropology. ${ }^{61}$ In these diverse research practices access to specific documents and social environments became pivotal.

Cambridge historians and philosophers frequently worked at home during their research leave (usually completing a book), travelled to continental Europe, or used libraries and archives in the United States (Figure 4b). Involving argumentativeinterpretative research practices that required rare books and archival material from a particular temporal and regional context, the work of historians and philosophers was bound to culturally transformed places that were not necessarily linked to powerful research institutions but were rather constituted by traces of human 
activity as preserved in libraries, archives and museums. Their geographical focus on Europe before World War Two (every fourth research leave) and on Europe and the United States in the post-war decade (every third research leave respectively) resulted from a profoundly European research tradition that considered both regions as epitomizing modernity, thereby neglecting the history and philosophy of other regions. ${ }^{62}$ Interestingly, the global geographies of research travel in both historical and philosophical as well as cultural and language studies had an emphasis on Europe from the 1880 s to the 1950 s, but they differed in the post-1945 decade through a greater US-centrism of the former and a stronger preference for far-flung places of the latter, especially in Asia. This reflects not only wider changes in global geopolitics but also the ongoing specialization of research, facilitated by a new phase in the globalization of scholarship due to rapid developments in long-distance transport and communication.

As part of an emerging disciplinary division of labour in the early twentieth century, it was the task of anthropologists to work on cultures outside Europe and North America, many of which lacked written record and thus required field work and observation. In 1914, the same year when Bronisław Malinowski, the protagonist of participant observation in ethnographic field work, went on his famous trip to Papua and the Trobriand Islands, Alfred Cort Haddon, who had been appointed to a Readership in Ethnology at Cambridge in 1909 and was widely known for having organized and led the celebrated Cambridge anthropological expedition of 1898-99 to the Torres Strait and New Guinea, returned to his field sites in the far east. He had been invited by the Australian Government to undertake an ethnological investigation in Papua and planned to study the distribution of different 
canoe types. ${ }^{63}$ However, after attending the meeting of the British Association for the Advancement of Science in Australia, he faced complications when

he learnt that the streamer on which he was to have travelled around the Papuan coast was stranded $800 \mathrm{~km}$ up the Fly River and no other ship was available. So, instead of his study tour, Haddon, to his delight, was able to revisit Torres Strait ... Subsequently he and his daughter were invited by the Resident Magistrate to visit the Delta Division and so made a study of the canoes of the Gulf of Papua. Ultimately this research was developed into the major monograph he wrote with J. Hornell, Canoes of Oceania (1936). ${ }^{64}$

Based on this trip and his previous ethnographic field work in 1888 and 1898, Haddon also published a regional ethnography in six volumes that appeared in print between 1901 and 1935 and 'remains the seminal work in Torres Strait studies'. ${ }^{65}$ Despite Haddon's intensive ethnographic field work and the impressive output of this research, it took almost 40 years until the next Cambridge anthropologist went on field work during a research leave and until the 'more advanced approaches', primarily that of Malinowski at the London School of Economics, 'flourished in Cambridge under Sir Edmund Leach' ${ }^{66}$

In the social, economic and political sciences, the idea of travelling for research was only hesitantly accepted. After Wilson's trip to India in 1887, Walter Thomas Layton, Lecturer in Economics since 1908 and a contemporary on the university staff with John Maynard Keynes, was granted leave for travelling in the academic year $1914 / 15$, but this plan was interrupted by the outbreak of World War 
One and Layton's move to the Ministry of Munitions. ${ }^{67}$ It took another decade until the next social science scholar applied for research leave. This was Sir Dennis Holme Robertson, at the time Lecturer in Economics (since 1924) and later Professor of Political Economy (1944-57), who wished to spend the Michaelmas and Lent terms of 1926/27 for travelling in India and other eastern countries 'with the object not of pursuing any specialised piece of research, but of learning what I can about as many things as possible' ${ }^{68}$ For this journey that marked the beginning of frequent research travel in the social sciences and took the economist through Russia on the TransSiberian railway before returning via India and Egypt, Robertson thus adopted an educational approach inspired by the humanistic tradition of polite learning. A few years later, he accepted an invitation from the Indian Government 'to collaborate in an inquiry into Indian economic conditions and the present statistical organisation of India', ${ }^{69}$ which not only demonstrates the potentially beneficial impact of educational travel on future international collaborations but also exemplifies a strong link between consultancy work and research in the social sciences.

The wider move towards a more scientific understanding of research travel across all disciplines after the university reform of 1926 is evident in the particular empirical foci of subsequent research leaves by social scientists. For example, Henry Arthur Hollond, at the time Reader in English Law and later Rouse Ball Professor of English Law (1943-50), worked in the library of the Harvard Law School for six months in 1937/38, while Denis William Brogan, who had been elected to the Professorship of Political Science in 1939, observed the American presidential elections of 1948 and 1952 for a period of three months respectively. ${ }^{70}$ Others proposed to study the political conditions in central and south east Europe (1934), 
the practice of the French Civil Courts (1949), and the capital market in Australia $(1953 / 54)$, or planned to work for the Government of Uganda and for the East African Institute of Social Research at Makerere College (1954). ${ }^{71}$ The research practices that developed into the social sciences were so heterogeneous that they resembled a mélange of different travel cultures. Initially linked to polite learning, they concentrated mainly on documentary research and social scientific field work but embraced psychological laboratory work after the Second World War as well. ${ }^{72}$ Their uniting feature was gaining access to sources and environments for the study of contemporary social life worlds.

Most research travellers in the social, economic and political sciences went to the United States as a destination that combined renowned spaces of knowledge production with attractive research facilities and popular sites of study (Figure 4c, Table 2). Remarkably, the southern hemisphere attracted only five Cambridge research travellers from across the humanities and the social sciences between 1885/86 and 1954/55 (3 per cent), which suggests a distinct north-south divide in the production of humanistic knowledge at the time. ${ }^{73}$ All types of academic travel from Cambridge in the 1880 s to 1950 s neglected Latin America outside the British possessions, thus underlining the important influence of political interests and language on transnational academic exchange. Whereas French academics actively pursued teaching missions in Latin America, where the elites were 'in a subordinate position, were fascinated by French culture, and were often able to speak French', ${ }^{74}$ Cambridge academics flocked to the United States and Canada, particularly when techno scientific research flourished there after World War Two. 
[Table 2 about here]

\section{Scientific field work}

As discussed at the beginning of this essay, the implementation of a scientific approach to university-based research travel in Cambridge began to flourish after Arthur Eddington's famous eclipse expedition to the west coast of Africa in 1919 (Table 1$).{ }^{75}$ In the early twentieth century, observations of stars close to the sun could only be made during a total eclipse. Therefore, Eddington had to travel to a specific site along the path of the eclipse in order to take his valuable pictures. With the aim of raising the chances of observing this eclipse if meteorological or technical difficulties emerged at one site, the second expedition was sent to another point along the eclipse's trajectory located in northern Brazil. The political situations on Principe Island, a Portuguese colony, and in Brazil were both favourable for travelling there, and the necessary photographic equipment was successfully brought over from England. Cloudy skies initially complicated the measurements at both sites but as the clouds diminished at totality, the required configuration of the field site, necessary for completing the experiment, was eventually achieved. ${ }^{76}$

The significant impact of Eddington's and his colleagues' expeditions on scientific progress and public debate, resulting from the findings' interpretation as the first verification of Einstein's ideas on general relativity, drew attention to the unique value of travel as a research technique and boosted the interest in and acceptance of extended travels for scientific field work in the physical and biological sciences. Two years later, Albert Seward, Professor of Botany at Cambridge since 1906, applied for research leave in order to accompany a botanical expedition to 
Greenland for three weeks in the Easter term of 1921, while Joseph Barcroft, who was a Reader in Physiology at the time and became Professor of Physiology in 1925, wished to lead the Royal Society Expedition for the study of life at high altitudes in the Peruvian Andes during part of the Michaelmas term 1921/22. ${ }^{77}$

All three examples illustrate that scientific field work abroad often targeted remote places as it was rarely dependent on research infrastructure at the site of interest. This does not mean that researchers travelling to places outside Europe did not receive support from local people. On the contrary, recent work on exploration in Africa and elsewhere has revealed the extent to which scientific travellers were dependent on local guides, interpreters, porters and their local knowledges for doing the work, but instead of being 'exclusively scientific domains', field sites were rather 'public spaces', whose borders could not be 'rigorously guarded' ${ }^{78}$ Accordingly, the field sites at which Cambridge academics observed further eclipses, studied specific locations and collected plants, stones and other specimen, were widely dispersed across the globe (Figure 5a). While the United States and continental Europe were of minor importance for this type of research travel, most destinations were located in the British Empire and other regions, thus confirming the idea that 'colonial expansion was crucial for the development of sciences such as botany and geology, in which the collection and comparison of specimen was paramount' ${ }^{79}$

[Figure 5 about here] 
Laboratory science

Field work accounted for at least one quarter of research travel in the physical and biological sciences. More than half of these scientists spent their research leaves working in laboratories and field stations. Robert Kohler identified the border between laboratory and field sciences as 'one of the most important in the cultural geography of modern sciences. It cuts across a range of biological and physical sciences and demarcates differences of standing and credibility, physical location, and modes of scientific practices' ${ }^{80}$ While 'natural places are particular and variable places, none quite like another, each the result of a unique local history, never be the same from one moment to the next, unpredictable, unrepeatable, beyond human control ... Labs are separate, a world apart from the world' ${ }^{81}$

In this essay, we argue that the relatively late emergence of a travel culture in the laboratory sciences, a process that can be dated in Cambridge to the late 1920s and early 1930s, results from the conventional view of laboratory work as being 'ubiquitous'. As David N. Livingstone pointed out

the modern invention of the laboratory can be interpreted as a conscious effort to create a 'placeless' place to do science, a universal site where the influence of locality is eliminated. Securing credibility and achieving objectivity required 'placelessness', and the triumph of the laboratory as the site par excellence of scientific plausibility since the middle of the nineteenth century bears witness to this prevailing conviction. ${ }^{82}$ 
The moment when laboratory scientists from Cambridge began to travel to research centres in the United States, in continental Europe and in a few other places across the world thus marks their acknowledgement of a distinct geography of science, in which each site of knowledge production offers unique resources, ideas and collaborators that are often worth exploring in person. ${ }^{83}$ In both field and laboratory sciences, a similar amount of Cambridge academics travelled abroad but their research leaves targeted very different locations (Table 3). Most importantly, these geographies suggest that the higher prestige and credibility of laboratory work can paradoxically not only be attributed to its reputation as an apparently universal and placeless practice but to its very location within the global centres of knowledge production.

[Table 3 about here]

Highly specialised laboratory equipment and expertise required an immense input of money, training, machines and other resources that were mainly available in the richer regions of the world (Figure 5b). The predominance of research leaves in US laboratories resulted from a variety of factors such as growing Anglo-American ties based on a common English language; outstanding scientific achievements; increasing power, prestige and influence of US science; and the availability of up-todate research facilities. For example, before Sir Denys Wilkinson became Professor at Oxford and founded that institution's Nuclear Physics Laboratory in 1957, he lectured at Cambridge and spent his sabbatical of 1954/55 at two major particle accelerators in the United States: ${ }^{84}$ 
It is my wish to gain experience of research in the field of high energy physics and to perform certain experiments using the Cosmotron at Brookhaven National Laboratory, Long Island where protons of $2.3 \mathrm{BeV}$ are available and using the electron accelerator at Stanford University, California where electrons of the order $1 \mathrm{BeV}$ are produced. Each machine is unique in its own field and comparable facilities are to be found in no other laboratory. ${ }^{85}$

The availability of specific research infrastructure was so crucial for working in an overseas laboratory for an extended period that some research leaves, as the following by Russian born David Shoenberg, who worked as a Lecturer (1944-52), then Reader (1952-73) and later Professor of Physics (1973-78) at the Cavendish Laboratory, were postponed for a year or even longer:

In view of delays in the equipment of the low temperature laboratory at New Delhi I have decided not to take the leave of absence during $1952 / 53$... I shall go probably for a short visit to New Delhi during the Long Vacation and if the difficulties of the equipment can be overcome I may subsequently apply for leave of absence to work at New Delhi during 1953/54. ${ }^{86}$

Difficulties with obtaining visas also influenced the planning of research leaves abroad and favoured European and US research laboratories.

Dr William Alfred Wooster, renowned crystallographer at Cambridge (1927-60), had to change the plans outlined below and eventually spent his sabbatical of 1936 (January to September) in Norway, Sweden and Finland: ${ }^{87}$ 
I hope to do research in crystal physics in the Physical Institute, Kharkov, U.S.S.R. ... and have received permission to do so. I have not yet received a visa and should anything prevent me from going to Russia I intend to work in the laboratory of Professor Pauling, Gates Chemical Laboratory, California, U.S.A. ${ }^{88}$

Compared to the field sciences, where the original site of study and the centre of knowledge production often differed, these two places merged in the setting of laboratory experiments. Field stations that appeared first in the form of marine laboratories during the 1870 s were interesting hybrids in so far as these places 'express in their arrangement and natural surroundings the idea that laboratory objects and practices had become too enclosed and needed to be reconnected with the world of nature'.$^{89}$ In the early 1950s, three zoologists from Cambridge worked at the Laboratory of the East African Fisheries Research Organization at Jinja (Uganda) for six to twelve months respectively. ${ }^{90}$ Established by the British colonial government in 1947 and continuing its work as the National Fisheries Resources Research Institute of Uganda in the twenty-first century, this field station was designed to observe the development of fishery in Lake Victoria and to produce new knowledge about tropical waters more generally. ${ }^{91}$

Despite the existence of such hybrid spaces, the comparison of field work and laboratory research in the physical and biological sciences has shown that the former, involving the exploration of physical territories and the collection of samples by the scientists themselves, was confined to the physical reality of particular field sites. As these practices did not require any special on-site infrastructure (other than 
the equipment the researchers brought along), travel destinations for field work in the physical and biological sciences were scattered in various, and often remote, places across the globe. Laboratory work also depended on the materiality of a particular site but the highly specialised equipment required ongoing investment of economic and cultural capital in situ, thus leading to regional clusters of attractive travel destinations in the most affluent places of the global north, namely the United States and Europe (Table 3).

In the three decades from $1925 / 26$ to $1954 / 55$, the physical and biological sciences accounted for half of all research leaves (Figure 3a). Professors in the physical, biological and social sciences took more frequent research leaves than those in other disciplines but these tended to be shorter than in mathematics and in the humanities, where more than half of those leaves were longer than three months. ${ }^{92}$ When the travels of Cambridge academics became gradually dominated by the sciences, the scientific approach to research transformed the other travel cultures as well, primarily by making them more goal- and output-orientated. The need to travel for other aspects of academic work also grew strongest in the natural sciences, particularly for conference attendance, which was closely linked to a growing significance of international research collaborations and a highly competitive environment that required frequent access to the newest research findings produced elsewhere. The resulting, distinct change in the disciplinary profile of academic leaves in Cambridge from three fourth undertaken by humanities scholars and social scientists in the 1880 s to three fifth arranged by natural and technical scientists in the 1950s was part of a wider shift towards an emphasis on 
knowledge production in science, technology, engineering and medicine during the twentieth century (Figure $3 b) .{ }^{93}$

Theoretical scientific research

The new travel regimes were largely motivated by unmediated access to specialised documents, social and cultural life worlds, natural and built environments, research infrastructure and collaborators. This raises the question whether mathematicians and other theoretical scientists began to travel as well, given that most of them worked on their own, using mainly pen and paper.

The records confirm that a travel culture eventually developed in the theoretical sciences but this was a fairly late process, coming to fruition only in the second half of the 1930s. Dealing with highly specialised knowledge, ideas and formulas, attractive mathematical resources that provided incentives for travelling were only to be found in a few selected places with highly trained and talented individuals who previously had enough economic capital at their disposal to become an expert in mathematics. ${ }^{94}$ These colleagues, who mostly served as partners for informal mathematical conversations, were the reason for why in a field characterised by conceptual rather than physical sites of study, research travel occurred at all:

I am proposing to visit the University of Nancy, in order to work with the group of active mathematicians at that University; in particular, I wish to investigate the applications of the theory of Banach algebras and generalisations thereof 
to mathematical analysis, with a special view to possible applications to the problem of the closure of the translations of a function in a function-space. ${ }^{95}$

The global geographies of research travel in mathematics were much more influenced by centres of academic excellence than in those fields, in which the physicality of the site of study mattered. This concentration on a few knowledge centres was so high that half of the 26 mathematicians who were granted research leave between 1925/26 and 1954/55 went to the United States (Figure 5c). The only other overseas destinations were France, Australia and an undisclosed location with one research leave respectively.

The great appeal of a close interaction with renowned individuals and research groups is underlined by the 15 visiting appointments of Cambridge mathematicians from $1928 / 29$ to $1954 / 55$. While all were held in the United States, ten involved either Princeton University or the Princeton Institute for Advanced Study, where Albert Einstein, Kurt Gödel and John von Neumann, among others, had worked since their emigration from central Europe in the 1930 s. ${ }^{96}$ For example, the mathematical giant Godfrey Hardy, who had sustained a unique collaboration with his professorial colleague and Trinity college fellow John Littlewood at Cambridge, a collaboration that is said to have 'dominated the English mathematical scene for the first half of the twentieth century', ${ }^{97}$ spent a term at the Institute for Advanced Study in 1936. The equally distinguished theoretical physicist Paul Dirac, Lucasian Professor of Mathematics since 1932 and Nobel laureate of 1933, worked there for more than two academic years. ${ }^{98}$ Renowned for a certain unsociability, Dirac was characterised by a young visiting physicist from Poland as 'one of the very few 
scientists who could work even on a lonely island if he had a library and [he] could perhaps even do without books and journals'.$^{99}$ However, even if he kept working alone when being abroad, Dirac seemed to benefit from the 'intense intellectual environment' he experienced in the places he visited. ${ }^{100}$

The research practices of mathematicians and theoretical physicists involved mainly (transportable) books and ideas as well as conceptual sites of study. Therefore, their work could have theoretically been done in a variety of places, but this often meant that there was no need to travel at all, and if so, the prospects of shared conversations with like-minded colleagues and the acquisition of symbolic capital, or prestige, abroad were again only to be found in a few places spearheaded by the United States (Table 2).

\section{Conclusions}

This essay has begun to shed light on the development of research travel in the modern university. We have especially been interested in the emergence of new travel cultures and their impact on the nature of university-based science and scholarship. Our findings on research travel in the University of Cambridge from 1885 to 1955 can be summarized in three main points.

First, this study has shown that the introduction of the research leave in Cambridge in 1926 was a significant step for turning this ancient centre of learning into a modern research university. At British universities, the creation of a conducive research environment lagged considerably behind German and American universities, but we argue that embracing the concept of the periodic research leave - almost half a century after this innovation first appeared at Harvard University - 
became a long-term competitive advantage over other universities in Britain, Germany and elsewhere that only reluctantly developed a sabbatical culture. The advent of the research leave in Cambridge also contributed to a wider shift in the institutional support for science and scholarship in early twentieth century Europe from a range of state-funded organisations to universities. ${ }^{101}$

Second, the historical geography of research travel in Cambridge from the 1880 s to the 1950 s has documented the transformation of a largely sedentary academic community into one of the most mobile workforces of any institution. By directly shaping the travels of its academic staff, the University of Cambridge contributed to the emergence of a highly mobile population of researchers that foreshadowed economic globalization through the movement of a range of highly skilled professionals. Research travel from Cambridge specifically contributed to the globalization of science and scholarship through a growing internationalization of research and the intensification of Anglo-American ties, especially in the post-1945 decade and with a clear geographical focus on the global north.

Third, we identified the successive development of new travel cultures that profoundly shaped the evolution of modern disciplines. In the 1880s, when the first regulations on leave of absence produced records on research travel in Cambridge, linguists, classicists and archaeologists, among others, continued the earlier tradition of self-funded educational tourism within the new travel scheme provided and funded by the university. Practising cultures of polite learning, these scholars primarily went to the classical arenas of Mediterranean Europe but later extended their travels across the southern part of Asia towards Japan. Before the First World War, new and different travel cultures developed in historical and philosophical 
studies as well as in social scientific research that both increasingly required access to distant documents and social environments, located mainly in continental Europe and the United States. Triggered by Eddington's famous eclipse expedition to the west coast of Africa in 1919, cultures of scientific field work emerged in the physical and biological sciences after World War One, while research-related travel in the laboratory sciences developed only after the periodic research leave was introduced in 1926. Fuelled by an interest in keeping up-to-date with the latest scientific achievements in the United States, the latter reflects the appreciation of a distinct geography of science in a field with apparently ubiquitous research practices. Eventually, theoretical scientists embraced the idea of research travel in the 1930s. In contrast to the other travel regimes, their interest in travel was much more focused on shared conversations and the informal exchange of ideas rather than on gaining access to research objects, sites of study and collaborators.

After research travel from Cambridge had begun hesitantly in the 1880s, all fields of research were enrolled in the new travel paradigm by the late 1930s. Initially, travel had been more frequent in the humanities than in the natural sciences but the latter dominated research travel in Cambridge from the 1920s onwards. This change in the disciplinary profile of academic travellers resulted from a higher demand for travel in the physical and biological sciences and contributed to what Christophe Charle identified as 'a shift from the humanist paradigm to that of scientific research' ${ }^{102}$ Strikingly, this growing preponderance of travel for scientific research impacted on all travel cultures by making them more targeted and outputorientated. However, it remained the task of scholars in the humanities to provide a 
certain cultural and geographical diversity of knowledge production outside the prevailing techno scientific Anglo-American discourse.

In conclusion, our analysis has shown that the 1880 s to the 1950 s were the decisive period in which travel became the crucial research technique in Cambridge, thereby shaping geographical imaginations about field-specific research landscapes and the nature of the evolving disciplines. The new travel cultures created disciplinary identities by targeting specific spatial contexts that were either required by the different research practices or offered suitable intellectual, social and material resources. In some research specialisms, the potential and actual travel destinations were spatially more concentrated than in others but going to the same types of places impacted on the formation of a common identity in all fields. From the perspective of individual academics, travel contributed to the accumulation of important cultural capital as visiting certain libraries, field sites, universities or laboratories and establishing a network of relationships in prestige-rich knowledge centres became prerequisites for an academic career in all disciplines, whether these travels were linked to polite learning, the study of social environments, scientific field work, laboratory science, or theoretical scientific research. 


\section{Acknowledgements}

This essay is based on research jointly funded by the Alexander von Humboldt

Foundation, Germany, and the University of Nottingham, UK.

We are also grateful to Jacqueline Cox and her colleagues in the Cambridge

University Archives for patiently answering any questions; to Alexa Färber and Peter

Taylor for invaluable advice on earlier versions of this essay; and to Jon Agar and the anonymous readers for their constructive feedback on producing this final version. 


\section{Figures}

Figure 1 Granted academic leaves of absence in the University of Cambridge,

$1885 / 86$ to $1954 / 55$

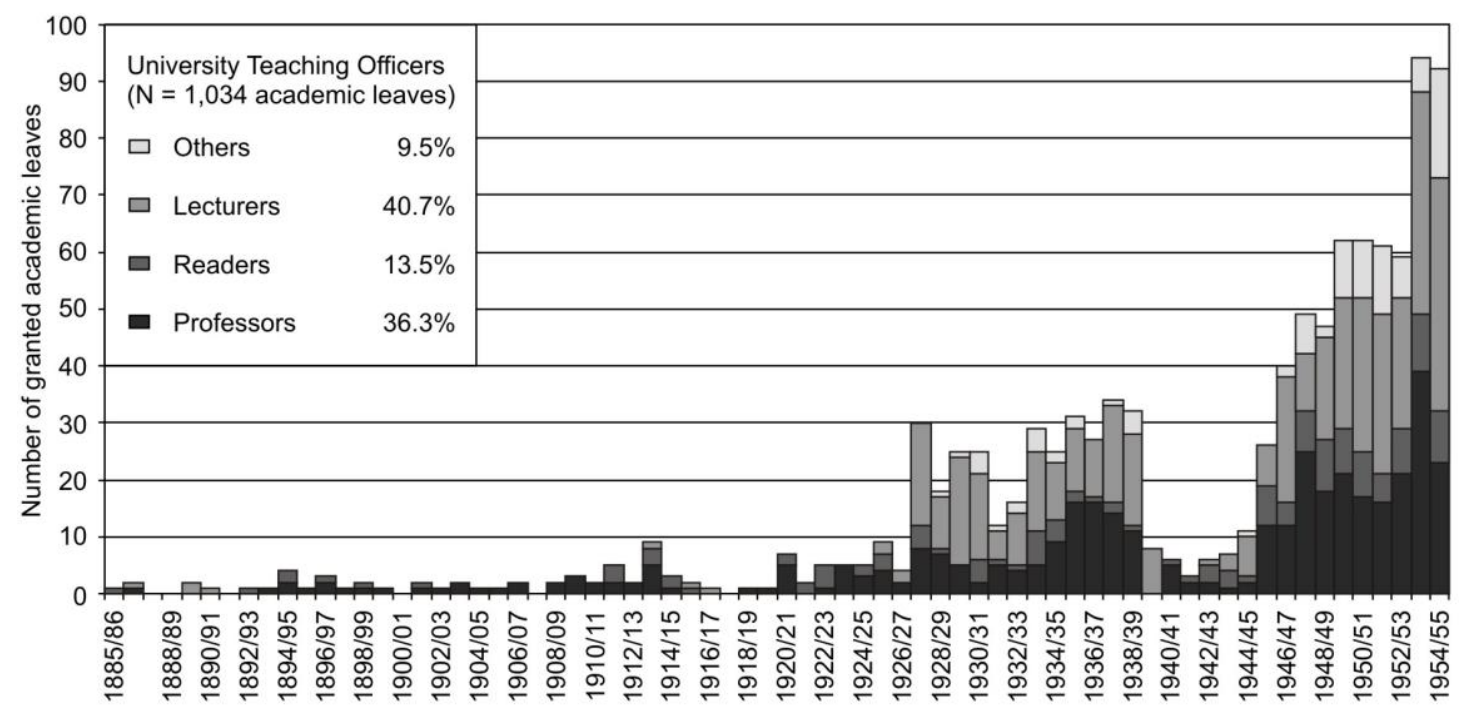

Sources: CUA, GB, Min III.1 to Min III.7 and GB, Box 301 to 308. 
Figure 2 Main purpose of granted academic leaves in the University of Cambridge, $1885 / 86$ to $1954 / 55$

(a) By decade

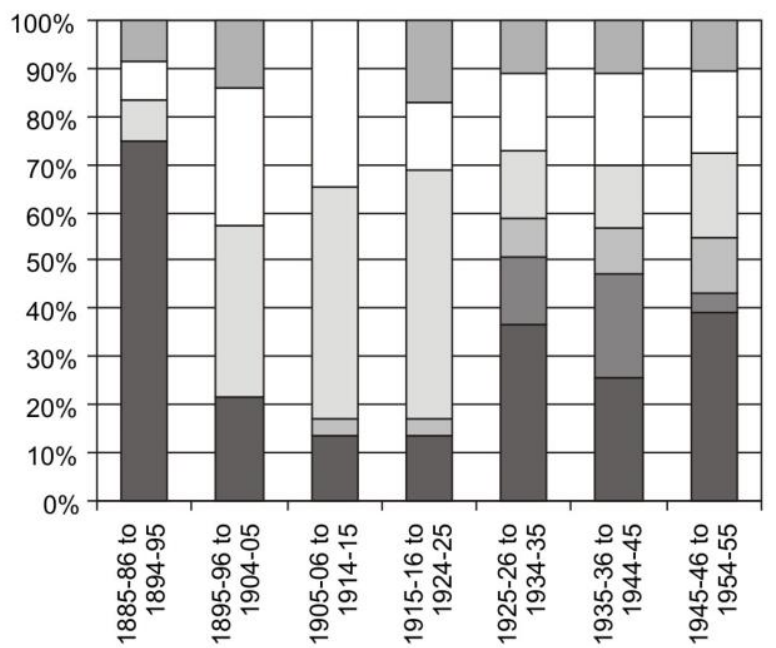

Main purpose of academic leave $(\mathrm{N}=1,034)$

$\square$ Consulting \& administration $\quad 18.2 \%$

$\square$ Conference \& representation $10.4 \%$

$\square$ Lecturing $17.9 \%$

$\square$ Visiting appointment

$\square$ Unspecified sabbatical leave

$\square$ Research \& travelling

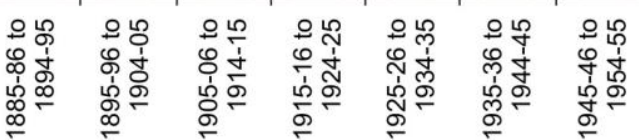

(b) By discipline

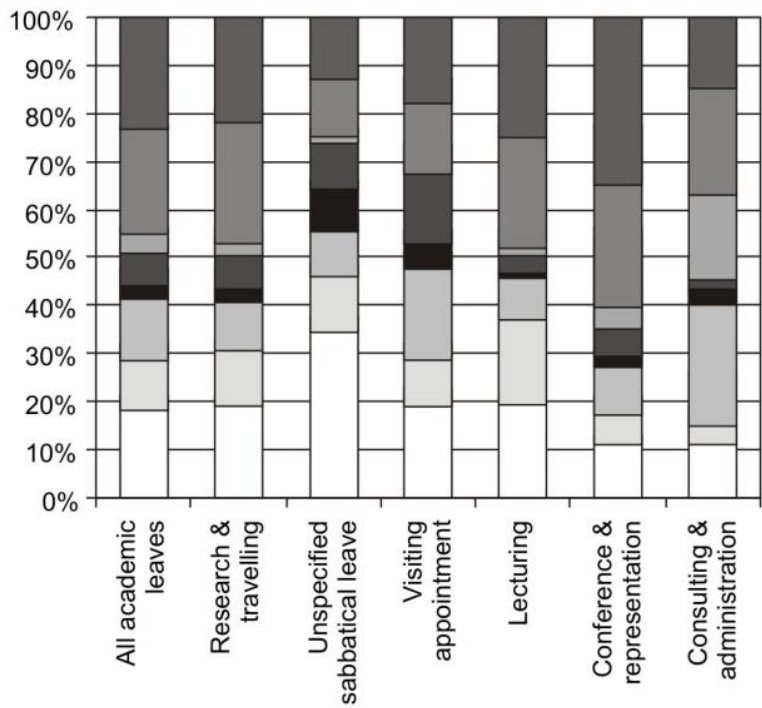

Disciplinary profile of academic leaves $(\mathrm{N}=1,034)$

$\square$ Physical sciences

$\square$ Biological sciences

$\square$ Agricultural sciences

- Mathematical sciences

$\square$ Social \& economical sciences

$\square$ Historical \& philosophical studies $10.6 \%$

$\square$ Language \& cultural studies

Sources: CUA, GB, Min III.1 to Min III.7 and GB, Box 301 to 308. 
Figure 3 Disciplinary profiles of granted academic leaves in the University of

\section{Cambridge by decade}

(a) Research leaves

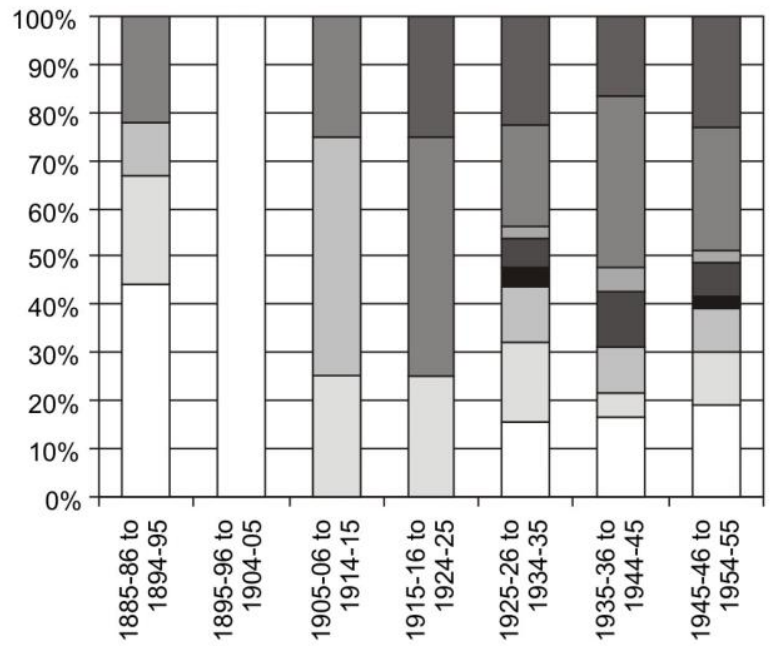

Disciplinary profile of research leaves $(\mathrm{N}=366)$

$\square$ Physical sciences

$\square$ Biological sciences

$\square$ Agricultural sciences

- Mathematical sciences

- Engineering sciences

$\square$ Social \& economical sciences

$\square$ Historical \& philosophical studies

(b) All academic leaves

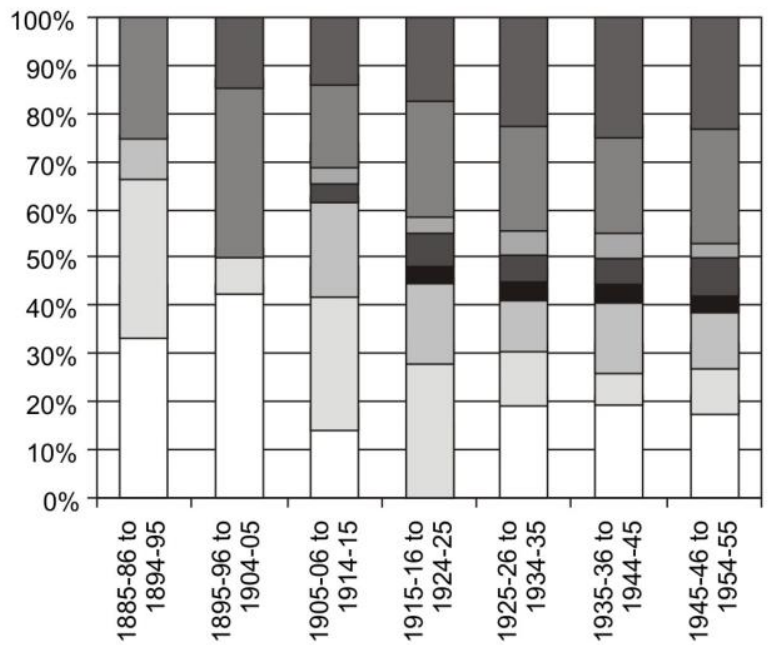

Disciplinary profile of academic leaves $(\mathrm{N}=1,034)$

$\square$ Physical sciences

$\square$ Biological sciences

$\square$ Agricultural sciences

- Mathematical sciences

$\square$ Social \& economical sciences

Sources: CUA, GB, Min III.1 to Min III.7 and GB, Box 301 to 308. 
Figure 4 Destinations of research leaves by Cambridge academics in the humanities and social sciences, $1885 / 86$ to $1954 / 55$

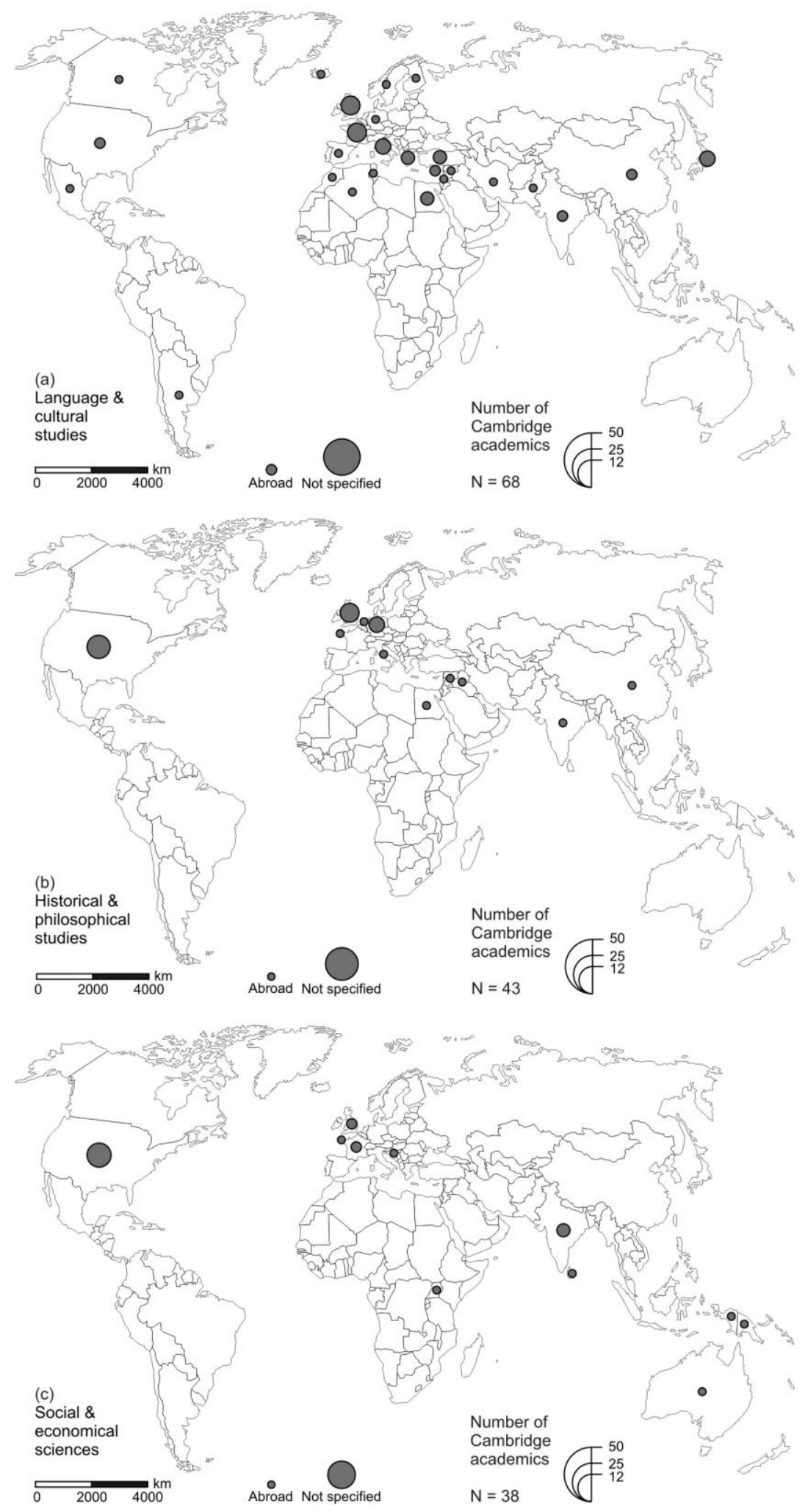

Sources: CUA, GB, Min III.1 to Min III.7 and GB, Box 301 to 308. 
Figure 5 Destinations of research leaves by Cambridge academics in the natural sciences, $1885 / 86$ to $1954 / 55$
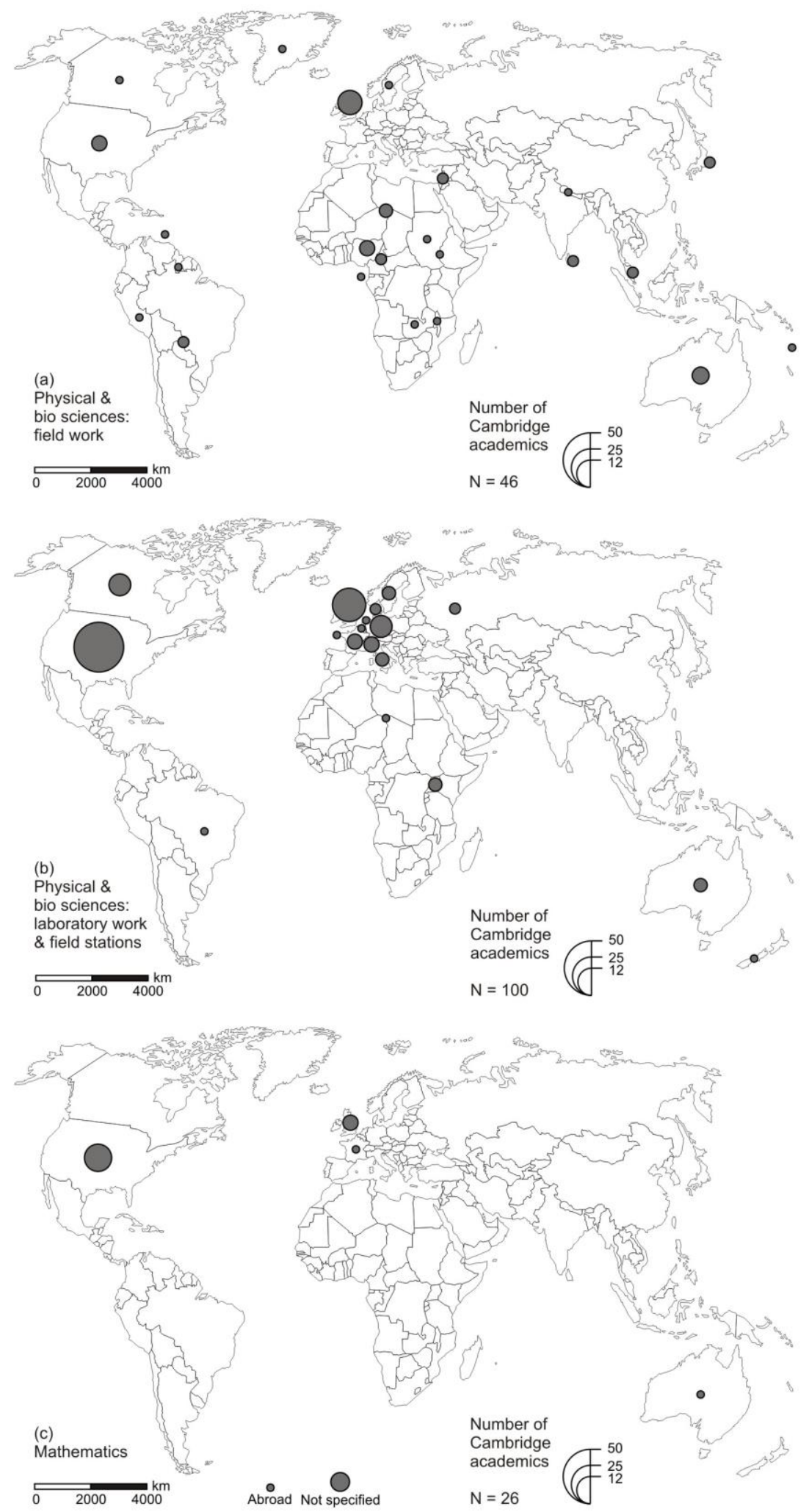

Sources: CUA, GB, Min III.1 to Min III.7 and GB, Box 301 to 308. 
Tables

Table 1 Applications of Cambridge academics for research leaves abroad by academic field, $1885 / 86$ to $1954 / 55$

\begin{tabular}{|c|c|c|c|}
\hline Academic field & $\begin{array}{l}\text { First } \\
\text { Entry }\end{array}$ & $\begin{array}{l}\text { Second } \\
\text { entry (specified) }\end{array}$ & $\begin{array}{l}\text { Third } \\
\text { entry (specified) }\end{array}$ \\
\hline $\begin{array}{l}\text { Language and } \\
\text { Cultural Studies }\end{array}$ & $\begin{array}{l}\text { 1889-90: } 2 \text { mos } \\
\text { Cyprus/Syria } \\
\text { Edward Browne }\end{array}$ & $\begin{array}{l}\text { 1896-97: } 2 \text { wks } \\
\text { Greece } \\
\text { Charles Waldstein }\end{array}$ & $\begin{array}{l}\text { 1898-99: } 3 \text { mos } \\
\text { Greece } \\
\text { Charles Waldstein }\end{array}$ \\
\hline $\begin{array}{l}\text { Historical and } \\
\text { Philosophical Studies }\end{array}$ & $\begin{array}{l}\text { 1890-91: } 3 \text { mos } \\
\text { Abroad } \\
\text { Arthur Tilley }\end{array}$ & $\begin{array}{l}\text { 1892-93: } 3 \text { mos } \\
\text { Italy } \\
\text { Solomon } \\
\text { Schechter }\end{array}$ & $\begin{array}{l}\text { 1908-09: } 2 \text { wks } \\
\text { Cont. Europe } \\
\text { Henry Sidgwick }\end{array}$ \\
\hline Social Sciences & $\begin{array}{l}\text { 1885-86: } 3 \text { mos } \\
\text { India (Law) }\end{array}$ & $\begin{array}{l}\text { 1913-14: } 3 \text { mos } \\
\text { Papua }\end{array}$ & $\begin{array}{l}\text { 1913-14: } 12 \text { mos } \\
\text { Travelling }\end{array}$ \\
\hline & Robert Wilson & Alfred Haddon & Walter Layton \\
\hline $\begin{array}{l}\text { Physical Sciences } \\
\text { (Field work) }\end{array}$ & $\begin{array}{l}\text { 1918-19: } 6 \text { mos } \\
\text { West Africa } \\
\text { Arthur Eddington }\end{array}$ & $\begin{array}{l}\text { 1927-28: } 3 \text { mos } \\
\text { Malaysia } \\
\text { Frederick Stratton }\end{array}$ & $\begin{array}{l}\text { 1927-28: } 3 \text { mos } \\
\text { Australia } \\
\text { Alfred Steers }\end{array}$ \\
\hline $\begin{array}{l}\text { Biological Sciences } \\
\text { (Field work) }\end{array}$ & $\begin{array}{l}\text { 1920-21: } 3 \text { wks } \\
\text { Greenland } \\
\text { Albert Seward }\end{array}$ & $\begin{array}{l}\text { 1921-22: P/O } \\
\text { term } \\
\text { Peru } \\
\text { Joseph Barcroft }\end{array}$ & $\begin{array}{l}\text { 1928-29: } 6 \text { mos } \\
\text { Australia } \\
\text { Sidnie Manton }\end{array}$ \\
\hline $\begin{array}{l}\text { Biological Sciences } \\
\text { (Laboratory work) }\end{array}$ & $\begin{array}{l}\text { 1927-28: } 6 \text { mos } \\
\text { United States } \\
\text { Francis Roughton }\end{array}$ & $\begin{array}{l}\text { 1930-31: } 8 \text { mos } \\
\text { United States } \\
\text { Edward Spooner }\end{array}$ & $\begin{array}{l}\text { 1931-32: } 6 \text { mos } \\
\text { Italy } \\
\text { Carl Pantin }\end{array}$ \\
\hline $\begin{array}{l}\text { Physical Sciences } \\
\text { (Laboratory work) }\end{array}$ & $\begin{array}{l}\text { 1929-30: } 3 \text { mos } \\
\text { Germany } \\
\text { Patrick Blackett }\end{array}$ & $\begin{array}{l}\text { 1929-30: } 3 \text { mos } \\
\text { United States } \\
\text { Eric Rideal }\end{array}$ & $\begin{array}{l}\text { 1930-31: } 6 \text { mos } \\
\text { United States } \\
\text { Cecil Tilley }\end{array}$ \\
\hline Mathem & $\begin{array}{l}\text { 1929-30*: } 6 \text { mos } \\
\text { United States }\end{array}$ & $\begin{array}{l}\text { 1936-37: } 12 \text { mos } \\
\text { Australia }\end{array}$ & $\begin{array}{l}\text { 1937-38: } 9 \text { mos } \\
\text { United States }\end{array}$ \\
\hline
\end{tabular}


Ralph Fowler Colin Clark Sydney Goldstein

Agricultural Sciences 1929-30: 12 mos

United States

1942-43: 5 mos

1944-45: 3 mos

Abroad

United States

Canada/NZ/Japan Frank Engledow

Ernest Childs

Ceylon/Java

John Venn

Engineering Sciences 1932-33: 3 mos

1933-34: 3 mos

1946-47: 2 mos

United States

West Indies/

United States

William Farren

South America

Terence Fox

Terence Sanders

Abbreviations

mos months

wks weeks

$\mathrm{P} / \mathrm{O}$ part of

NZ New Zealand

* $\quad$ First specified entry; the first entry was in 1925-26 when John Littlewood applied for research leave of three months but did not specify where he would take this leave.

Sources: CUA, GB, Min III.1 to Min III.7 and GB, Box 301 to 308. 
Table 2 Destinations of research leaves in the University of Cambridge by discipline, $1885 / 86$ to $1954 / 55$ (in per cent of research leaves)

Lan- Social \& Total

guage Histori- econo- Physica Biologi-Mathe- Agri- Engi- 1885/8 \& cal \& mical I cal matical cultural neering 6 cultural philo. science science science science science science 1954/5 $\begin{array}{llllllll}\text { Destination } & \text { studies Studies } S & \mathrm{~S} & \mathrm{~S} & \mathrm{~S} & \mathrm{~S} & \mathrm{~s} & 5\end{array}$

(1) United Kingdom of Great Britain and Ireland

$\begin{array}{rrrrrrrrrr} & 6 & 12 & 5 & 21 & 21 & 15 & 11 & 11 & 14 \\ \text { thereof } & & 7 & 3 & 6 & 5 & 15 & 0 & 11 & 6\end{array}$

$\begin{array}{llllllllll}\text { (2) Abroad } & 62 & 47 & 61 & 74 & 72 & 62 & 89 & 78 & 66\end{array}$

(a) British Empire overseas (as of 1914)

$\begin{array}{lllllllll}12 & 2 & 21 & 19 & 21 & 4 & 22 & 22 & 16\end{array}$

(b) United States of America $\begin{array}{lllllllll}3 & 21 & 26 & 31 & 29 & 50 & 56 & 56 & 26\end{array}$

(c) Continental

Europe

$\begin{array}{lllllllll}25 & 16 & 11 & 14 & 17 & 4 & 11 & 0 & 16\end{array}$

thereof Germany

(d) Other places

$24 \quad 7 \quad 0 \quad 18$

(3) Not specified

32

42

34

$68 \quad 43$

38

78

95

26

9

9

366

Sources: CUA, GB, Min III.1 to Min III.7 and GB, Box 301 to 308. 
Table 3 Destinations of research leaves by Cambridge academics in the physical and biological sciences, $1885 / 86$ to $1954 / 55$ (in per cent of research leaves)

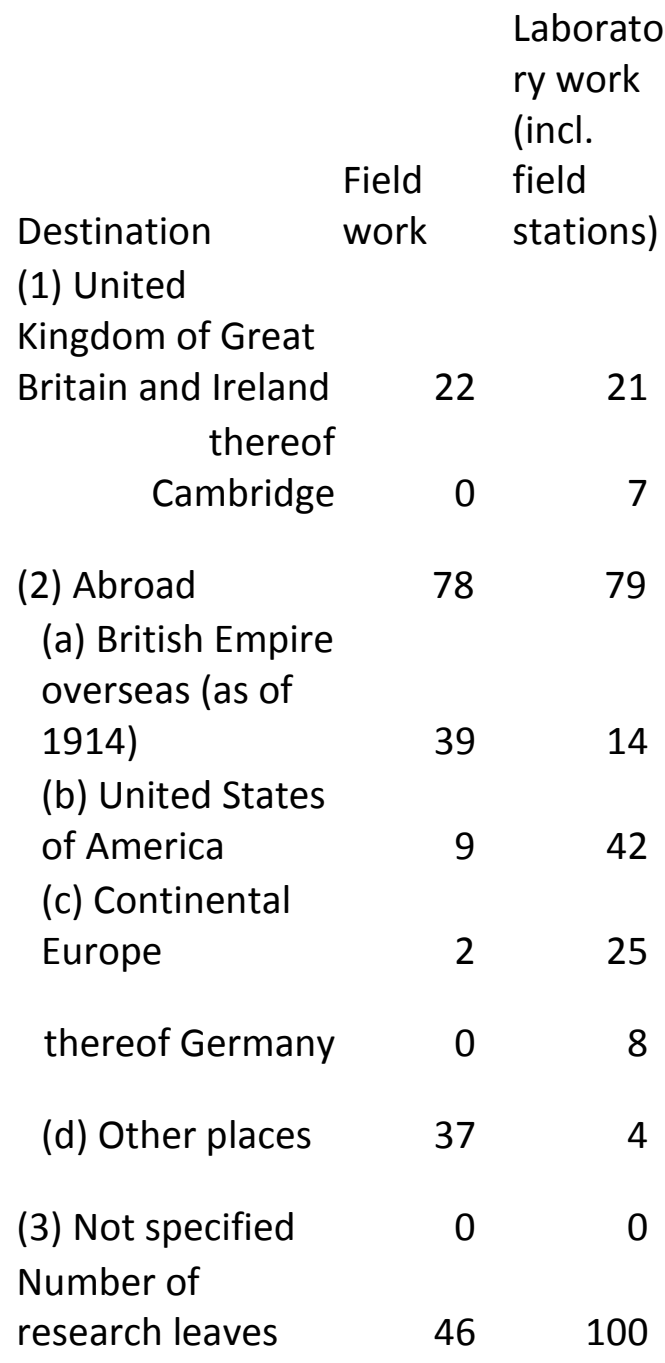

Sources: CUA, GB, Min III.1 to Min III.7 and GB, Box 301 to 308. 


\section{Endnotes}

${ }^{1}$ Arthur S. Eddington to William L. Mollison, 23 October 1918, Cambridge University Archives (subsequently CUA), Minutes of Proceedings at a Meeting of the General Board (subsequently GB), Min III.3, 67. See also Malcolm Longair, 'Arthur Stanley Eddington', in Peter Harman and Simon Mitton (eds.), Cambridge Scientific Minds, Cambridge: Cambridge University Press, 2002, pp. 220-239, especially pp. 230-231.

${ }^{2}$ Frank W. Dyson, Arthur S. Eddington and Charles Davidson, 'A determination of the deflection of light by the sun's gravitational field, from observations made at the Total Eclipse of May 29, 1919', Philosophical Transactions of the Royal Society of London A (1920) 220, pp. 291-333. For details on the two expeditions, see John Earman and Clark Glymour, 'Relativity and eclipses: the British eclipse expeditions of 1919', Historical Studies in the Physical Sciences (1980) 11, pp. 49-85.

${ }^{3}$ For a critical discussion of the experiments and their results, see John Waller, Fabulous Science: Fact and Fiction in the History of Scientific Discovery, Oxford: Oxford University Press, 1996, pp. 49-63.

${ }^{4}$ A request, submitted in the autumn of 1912, from William Emery Barnes, Hulsean Professor of Divinity, for leave to undertake a six-month visit to Malta was received with bewilderment by the university's General Board and required written support by his colleague Francis Crawford Burkitt, Norris Professor of Divinity. See Francis Crawford Burkitt to William Emery Barnes, 20 October 1912, CUA, GB, Min III.2, 264.

${ }^{5}$ On the constitutive significance of travel and exploration in the formation of eighteenth- and nineteenth-century scientific culture, see, for example, Felix Driver, Geography Militant: Cultures of Exploration and Empire, Oxford: Blackwell, 2001 and Charles W. J. Withers, Placing the Enlightenment: Thinking Geographically about the Age of Reason, Chicago: University of Chicago Press, 2007. On the challenges of travel and exploration for eighteenth century science, see Dorinda Outram, 'On being Perseus: new knowledge, dislocation and Enlightenment exploration', in David N. Livingstone and Charles W. J. Withers (eds.), Geography and Enlightenment, Chicago: University of Chicago Press, 1999, pp. 281-294. Derek Gregory, 'Cultures of travel and spatial formations of knowledge', Erdkunde (2000) 54, 
pp. 297-319 explores the relationship between the travellers' routes and their texts in nineteenth-century science. The role of travel in the production of knowledge prior to the eighteenth century is discussed by Steven J. Harris, 'Long-distance corporations, big sciences, and the geography of knowledge', Configurations (1998) 6, pp. 269-304 and Dominik Collet, 'Big sciences, open networks, and global collecting in early museums', in Peter Meusburger, David N. Livingstone and Heike Jöns (eds.), Geographies of Science, Dordrecht: Springer, 2010, pp. 121-137. For scientific travels in Europe from the sixteenth to the nineteenth centuries, see Ana Simões, Ana Carneiro and Maria P. Diogo (eds.), Travels of Learning: A Geography of Science in Europe, Dordrecht: Springer, 2003.

${ }^{6}$ For a rare comparable investigation, see Christophe Charle, 'The intellectual networks of two leading universities: Paris and Berlin, 1890-1930', in Christophe Charle, Jürgen Schriewer and Peter Wagner (eds.), Transnational Intellectual Networks: Forms of Academic Knowledge and the Search for Cultural Identities, Frankfurt: Campus, 2004, pp. 401-450. See also Heike Jöns, 'Academic travel from Cambridge University and the formation of centres of knowledge, 1885-1954', Journal of Historical Geography (2008) 34, pp. 338-362. ${ }^{7}$ Crosbie Smith and Jon Agar (eds.), Making Space for Science: Territorial Themes in the Shaping of Knowledge, Basingstoke: Macmillan, 1998 and David N. Livingstone, Putting Science in Its Place: Geographies of Scientific Knowledge, Chicago: University of Chicago Press, 2003 provide excellent reviews, supplemented by Diarmid A. Finnegan, 'The spatial turn: geographical approaches in the history of science', Journal of the History of Biology (2008) 41, pp. 369-88; David N. Livingstone, 'The spaces of knowledge: contributions towards a historical geography of science', Environment and Planning D: Society and Space (1995) 13, pp. 5-34; and Adi Ophir and Steven Shapin, 'The place of knowledge: a methodological survey', Science in Context (1991) 4, pp. 3-21. James A. Secord, 'Knowledge in transit', Isis (2004) 95, pp. 654-72 recently suggested a greater emphasis on processes of movement and transmission in the history of science.

${ }^{8}$ See, for example, the classic investigation by Bruno Latour, Science in Action: How to Follow Scientists and Engineers through Society, Cambridge, MA: Harvard University Press, 1987. 
${ }^{9}$ For the second half of the twentieth century, this is highlighted by Philip G. Altbach, 'The new internationalism: foreign students and scholars', Studies in Higher Education (1989) 14, pp. 125-136; Heike Jöns, "Brain circulation" and transnational knowledge networks: studying long-term effects of academic mobility to Germany, 1954-2000', Global Networks (2009) 9, pp. 315-338; and Anthony R. Welch, 'The peripatetic professor: the internationalisation of the academic profession', Higher Education (1997) 34, pp. 323-345.

${ }^{10}$ Christopher N. L. Brooke, A History of the University of Cambridge: Volume IV, 1870-1990, Cambridge: Cambridge University Press, 1993, p. 354. Tamson Pietsch, Universities and Empire: Academic Networks and the British World, 1850-1939, Manchester: Manchester University Press, forthcoming 2012 points out that Australian and Canadian universities facilitated travel abroad for their academics in the mid-nineteenth century to stay in touch with European centres of knowledge, either by introducing application procedures (in the University of Sydney since the 1860s) or by extending the length of the summer vacation (at King's College in Toronto since the 1840s). These leave of absence practices, however, were not formalised before the 1880 s, and fully paid sabbatical schemes were only established from the 1930s.

${ }^{11}$ For rare commentaries, see Walter C. Eells and Ernest V. Hollis, Sabbatical Leave in American Higher Education, Washington: US Department of Health, Education, and Welfare, 1962; and Celina M. Sima, 'The role and benefits of the sabbatical leave in faculty development and satisfaction', New Directions for Institutional Research (2000) 105, pp. 6775.

${ }^{12}$ Recent examples include Richard C. Powell, "'The rigours of an arctic experiment”: the precarious authority of field practices in the Canadian High Arctic, 1958-1970', Environment and Planning A (2007) 39, pp. 1794-1811; Robert Mayhew, 'Mapping science's imagined community: geography as a Republic of Letters, 1600-1800', British Journal for the History of Science (2005) 38, pp. 73-92; David S. Lux and Harold J. Cook, 'Closed circles or open networks? Communicating at a distance during the scientific revolution', History of Science (1998) 36, pp. 179-211; and Tamson Pietsch, 'Wandering scholars? Academic mobility and the British World, 1850-1940', Journal of Historical Geography (2010) 36, pp. 377-387. 
${ }^{13}$ The constitutive role of travel for research practice is emphasised by Michael J. Heffernan, 'A state scholarship: the political geography of French international science during the nineteenth century', Transactions of the Institute of British Geographers (1994) 19, pp. 21-45. ${ }^{14}$ Ronald Barnett and Alison Phipps, 'Academic travel: modes and directions', The Review of Education, Pedagogy, and Cultural Studies (2005) 27, pp. 3-16, pp. 5-6, pp. 11-13.

${ }^{15}$ Ana Simões, Ana Carneiro and Maria P. Diogo, 'Travels of learning: introductory remarks', in Ana Simões, Ana Carneiro and Maria P. Diogo (eds.), Travels of Learning: A Geography of Science in Europe, Dordrecht: Springer, 2003, pp. 1-18. See also Hanno Beck, 'Geography and travel in the nineteenth century: prolegomena to a general history of travel (1957)', in Gary S. Dunbar (ed.), The History of Geography: Translations of some French and German Essays, Malibu: Undena Publications, 1983, pp. 73-102.

${ }^{16}$ David N. Livingstone, The Geographical Tradition, Oxford: Blackwell, 1992, p. 126; David R. Stoddart, On Geography and its History, Oxford: Blackwell, 1986, p. 33.

17 Joseph Conrad labelled the period between James Cook's oceanic voyages into the Pacific and David Livingstone's continental explorations in Africa the age of 'Geography Militant', i.e. a time when explorers and scientific travellers revealed the secrets about yet unknown places in the world. This was apparently followed by 'Geography Triumphant', an era in which the aims of explorations had become 'scientific rather than narrowly geographical or for personal or nationalistic ends ... because of the professionalization and institutionalisation of science at that time.' James Ryan and Simon Naylor have challenged this view by arguing that it 'unintentionally exacerbates the idea of a rupture that in many ways was a fiction. Put another way, scientifically motivated exploration extended backwards in time well before 1900, while heroic exploration traditionally associated with the Victorian era extended well into the twentieth century'. See James R. Ryan and Simon Naylor, 'Exploration and the twentieth century', in Simon Naylor and James R. Ryan (ed.), New Spaces of Exploration: Geographies of Discovery in the Twentieth Century, London: I. B. Tauris, 2010, pp. 1-22, pp. 9-11. ${ }^{18}$ Since the 1970s, exploration has been discussed 'less as some impartial means of "discovering" the "unknown" than part of a powerful and enduring projection of Western imperial interests onto other parts of the world'; Ryan and Naylor, op. cit. (17), p. 1. See also Felix Driver, 'Distance \& disturbance: travel, exploration and knowledge in the nineteenth 
century', Transactions of the Royal Historical Society (2004) 14, pp. 73-92; Michael Heffernan, 'Histories of geography', in Sarah L. Holloway, Stephen P. Rice and Gill Valentine (ed.) Key Concepts in Geography, London, 2003, pp. 3-22; and Simon Naylor and James R. Ryan, New Spaces of Exploration: Geographies of Discovery in the Twentieth Century, London: I. B. Tauris, 2010.

${ }^{19}$ For detailed accounts, see Jeremy Black, The British and the Grand Tour, London: Croom Helm, 1985; Jeremy Black, The British Abroad: The Grand Tour in the Eighteenth Century, New York: St. Martin's Press, 1992; and Christopher Hibbert, The Grand Tour, London: Spring Books, 1974.

${ }^{20}$ Edward Brodsky-Porges, 'The grand tour: travel as an educational device, 1600-1800', Annals of Tourism Research (1981) 8, pp. 171-186, p. 183. On the history of Thomas Cook, see Jill Hamilton, Thomas Cook: The Holiday-Maker, Stroud: Sutton Publishing, 2005.

${ }^{21}$ M. Foucher, Fragments d'Europe, Paris: Fayard, 1993, pp. 23-24.

${ }^{22}$ Peter Burke, A Social History of Knowledge: From Gutenberg to Diderot, Cambridge: Polity, 2000, p. 21; Hilde De Ridder-Symoens, 'The changing face of centres of learning, 14001700', in Alasdair A. MacDonald and Michael W. Twomey (ed.), Schooling and Society: The Ordering and Reordering of Knowledge in the Western Middle Ages, Leuven: Peeters, 2004, pp. 115-138.

${ }^{23}$ Burke, op. cit. (22), pp. 49-51.

${ }^{24}$ In the sixteenth century, academies were founded for the discussion of humanist ideas beyond the reach of the establishment. By the time these ideas had entered university curricula, the scientific revolution was well under way, inspiring the foundation of the Royal Society in London (1660) and the Académie Royale des Sciences in Paris (1666) with their emphasis on the study of nature. In the eighteenth century, the very idea of 'research' appeared on the scene, based on the awareness that there is a need for searches of knowledge to be systematic, professional, useful and co-operative. This century became the age of academies that organized knowledge-gathering expeditions, offered prizes and increasingly formed an international network. For details, see Burke, op. cit. (22), pp. 33-51. ${ }^{25}$ Burke, op. cit. (22), p. 49. Peter J. Taylor, Michael Hoyler and David Evans, 'A geohistorical study of "the rise of modern science": mapping scientific practice through urban networks, 
1500-1900', Minerva (2008) 46, 391-394 visualised the shifting geographies of universitybased knowledge centres in Europe from the sixteenth to the nineteenth centuries based on the work places and career paths of one thousand leading 'scientists'.

${ }^{26}$ On Cook, see, for example, Nicholas Thomas, Cook: The Extraordinary Voyages of Captain Cook, New York: Walker \& Company, 2004; On Banks, see Tim Fulford, Debbie Lee and Peter J. Kitson, Literature, Science and Exploration in the Romantic Era: Bodies of Knowledge, Cambridge: Cambridge University Press, 2004; on von Humboldt, see Nicolaas A. Rupke, Alexander Von Humboldt: A Metabiography, Chicago: University of Chicago Press, 2008; and on Livingstone's travels, see Lawrence Dritsas, 'From Lake Nyassa to Philadelphia: a geography of the Zambesi expedition, 1858-64', British Journal for the History of Science (2005) 38, pp. 35-52. See also Felix Driver and Lowri Jones, Hidden Histories of Exploration, London: Royal Geographical Society, 2009 and note 5.

${ }^{27}$ Prevailing national perspectives on academic mobility are evident, for example, in Mike Byram and Fred Dervin (eds.), Students, Staff and Academic Mobility in Higher Education, Newcastle: Cambridge Scholars Publishing, 2008.

${ }^{28}$ For such a comparative perspective, see Heike Jöns, 'Transnational mobility and the spaces of knowledge production: a comparison of global patterns, motivations and collaborations in different academic fields', Social Geography (2007) 2, pp. 97-114. Without attending to travel behaviour, field-specific research cultures have been explored by Tony Becher and Paul R. Trowler, Academic Tribes and Territories: Intellectual Enquiry and the Culture of Disciplines, Second Edition, Buckingham: Open University Press, 2001; see also Karin D. Knorr-Cetina, Epistemic Cultures: How the Sciences Make Knowledge, Cambridge, MA: Harvard University Press, 1999 and Barbara H. Smith, 'Disciplinary cultures and tribal warfare: the sciences and the humanities today', in Barbara H. Smith, Scandalous Knowledge: Science, Truth and the Human, Edinburgh: Edinburgh University Press, 2005, pp. 108-129.

${ }^{29}$ Derek Gregory, 'The geographical discourse of modernity', in Derek Gregory (ed.) Explorations in Critical Human Geography, Heidelberg: University of Heidelberg, 1998, pp. 45-67.

${ }^{30}$ Gregory, op. cit. (29), pp. 57-58. 
${ }^{31}$ Latour, op. cit. (8), p. 161.

${ }^{32}$ Felix Driver used the term 'field' to describe 'the heterogeneous nature of geographical knowledge before the formation of modern disciplines at the end of the nineteenth century'. See Driver, op. cit. (5), p. 2.

${ }^{33}$ As mentioned in note 6, Charle has done a comparable study for Paris and Berlin from 1880 to 1940 , but his study includes samples from different shorter periods and does not cover all subjects.

${ }^{34}$ This explains why from $1885 / 86$ to $1954 / 55$ less than one per cent of recorded applications for academic leave were not granted.

${ }^{35}$ Journeys exceeding the duration of three months are best covered as this was the length of the Long Vacation in the summer and thus required leave of absence for those parts of the adjacent terms that were missed. Most research leaves from the University of Cambridge lasted longer than three months ( 45 per cent), followed by leaves of more than one to three months (39 per cent) and shorter leaves of up to one month (13 per cent; 4 per cent had no specified length). For sources on the first regulations for leave of absence, see note 46 .

${ }^{36}$ Charle, op. cit. (6), p. 425.

${ }^{37}$ Christophe Charle, 'Patterns', in Walter Rüegg (ed.), A History of the University in Europe:

Volume III: Universities in the Nineteenth and Early Twentieth Centuries (1800-1945),

Cambridge: Cambridge University Press, 2004, pp. 33-80.

${ }^{38}$ Edward Shils and John Roberts, 'The diffusion of European models outside Europe', in Walter Rüegg (ed.), A History of the University in Europe: Volume III: Universities in the Nineteenth and Early Twentieth Centuries (1800-1945), Cambridge: Cambridge University Press, 2004, pp. 163-230, p. 168; Daniel Fallon, 'German influences on American education', in Frank Trommler and Elliott Shore (eds.), The German-American Encounter: Conflict and Cooperation between Two Cultures, 1800-2000, New York: Berghahn Books, 2001, pp. 7787, pp. 83-84.

${ }^{39}$ William Clark, Academic Charisma and the Origins of the Research University, Chicago: University of Chicago Press, 2006, p. 463.

${ }^{40}$ Shils and Roberts, op. cit. (38), pp. 174-175.

${ }^{41}$ Brooke, op. cit. (10), p. xv. 
${ }^{42}$ Clark, op. cit. (39), p. 458.

${ }^{43}$ Clark, op. cit. (39), p. 459; Shils and Roberts, op. cit. (38), pp. 174-175.

${ }^{44}$ Renate Simpson, How the PhD Came to Britain: A Century of Struggle for Postgraduate Education, Guildford: Society for Research into Higher Education, 1983, p. 63.

${ }^{45}$ Clark. op. cit. (39), p. 459 and John Darwin, 'The growth of an international university', in John Prest (ed.), The Illustrated History of Oxford University, Oxford: Oxford University Press, 1993, pp. 336-370, p. 357.

${ }^{46}$ For residence requirements, see Statute B.XI.2, in University of Cambridge (ed.), Statutes of the University of Cambridge with Some Acts of Parliament relating to the University, Cambridge: Cambridge University Press, 1882, p. 61. The first regulations for leave of absence can be found in Cambridge University Reporter, $23^{\text {rd }}$ June 1885, p. 931, Grace No. 4 and Draft, for the General Board of Studies, 22 February 1886, CUA, GB, Min III.1, p. 109. ${ }^{47}$ The five main motivations for academic travel from Cambridge in the period 1885/86 to 1954/55 were research and travelling (35 per cent), visiting appointments (10 per cent), lecturing (18 per cent), conference visits and representation (18 per cent), consulting and administration (10 per cent). The remaining eight per cent were unspecified research leaves. For details, see Jöns, op. cit. (6).

${ }^{48}$ Walter C. Eells, 'The origin and early history of sabbatical leave', Bulletin, American Association of University Professors (1962) 48, pp. 253-256, p. 253. For the new regulations, see The Registrary of the University (ed.), Statutes of the University of Cambridge and Passages from Acts of Parliament Relating to the University, Cambridge: Cambridge University Press, 1928, pp. 40-41.

${ }^{49}$ In comparison, at least half of all visiting appointments were with full stipend; less than ten per cent were with reduced stipend (for example, at Cornell University and the University of Otago in Dunedin); and at least a quarter was without stipend from Cambridge and fully paid by the host university (for example, at Cairo University, Harvard Law School, M.I.T., University of Chicago, Yale Law School). Leave for consultancy work was frequently granted on the understanding that the institutions for which this work was undertaken would pay the university stipend (for example, the Colonial Office and the United Nations). 
${ }^{50}$ For Cambridge, see the correspondence between Burkitt and Barnes cited in note 4 and quoted in Jöns, op. cit. (6), pp. 346-347. The new regulations at Oxford aimed at encouraging applications for research leave; see Oxford University Archives, Hebdomadal Council Papers, Volume 220, p. 191 and Volume 221, pp. 9-10 and p. 275. Christopher Brooke also implied that Cambridge was the first British university to establish a sabbatical scheme (see note 10). ${ }^{51}$ Driver, op. cit. (5), p. 8.

${ }^{52}$ Nicholas Jardine and Emma Spary, 'The natures of cultural history', in Nicholas Jardine, James Secord and Emma Spary (eds.), Cultures of Natural History, Cambridge: Cambridge University Press, 1996, pp. 3-13.

${ }^{53}$ The records show that 15 of 366 granted research leaves were cancelled (4 per cent); five of those leaves had no specified destination, five targeted the United States, and the others were planned in Germany (two), France, Spain and India (one each).

${ }^{54}$ Brooke, op. cit. (10), p. 427.

${ }^{55}$ Minute of 17 March 1886, CUA, GB, Min III.1, p. 118. Francis Darwin, Lecturer in Botany, was also given research leave for the Lent Term 1887 in order to prepare for publication the letters of his father Dr Charles Darwin. See Minute of 15 November 1886, CUA, GB, Min III.1, p. 128.

${ }^{56}$ Minute of 4 January 1890, CUA, GB, Min III.1, p. 213; Minute of 16 November 1892, CUA, GB, Min III.1, p. 299.

${ }^{57}$ The rise and fall of applications for travel scholarships provided by the French Service de Missions between 1830 and 1914 can be interpreted as the heyday of 'a pioneering, amateur form of fieldwork and exploration that pre-dated the emergence of professional, universitybased research'. See Heffernan, op. cit. (13), p. 26.

${ }^{58}$ A similar geographical focus was to be found among scholars funded by the French Service de Mission between 1870 and 1914 as about 'a third of all post-1870 missions involved either a colonial or an Eastern Mediterranean destination'. This was the result of a 'compromise between intellectual curiosity, practical expediency and the political judgements of well-briefed scientists and scholars under the direct control of government officials and civil servants'. See Heffernan, op. cit. (13), pp. 28-29 and p. 34.

${ }^{59}$ Minute of 19 November 1902, CUA, GB, Min III.2, p. 20. 
${ }^{60}$ Minute of 22 April 1953, CUA, GB, Box 307, p. 160.

${ }^{61}$ Anthropology is discussed here as a social science. Despite the departmental affiliation with archaeology in Cambridge, applications for archaeological research were classified under language and cultural studies.

${ }^{62}$ Derek Gregory, 'Power, knowledge and geography', in Derek Gregory (ed.), Explorations in Critical Human Geography, Heidelberg: University of Heidelberg, 1998, pp. 9-40, pp. 15-22.

${ }^{63}$ Minute of 19 November 1913, CUA, GB, Min III.2, p. 296.

${ }^{64}$ David R. Moore, The Torres Strait Collections of A.C. Haddon: A Descriptive Catalogue, London: British Museum Publications, 1984, p. 12.

${ }^{65}$ Moore, op. cit. (64), p. 12.

${ }^{66}$ Brooke, op. cit. (10), p. 205; Reo Franklin Fortune, Lecturer in Anthropology, planned to work in New Guinea in 1951/52; see Minute of 6 June 1951, CUA, GB, Box 306, p. 247.

${ }^{67}$ Minute of 10 May 1914, CUA, GB, Min III.2, p. 312. See also Peter Groenewegen, 'Walter Layton on The Relations of Capital and Labour (1914): A Marshallian text pur sang? History of Economics Review (2007) 46, pp. 19-31.

${ }^{68}$ Minute of 9 June 1926, CUA, GB, Min III.4, p. 38.

${ }^{69}$ Minute of 1 November 1933, CUA, GB, Min III.7, p. 59.

${ }^{70}$ Minute of 3 March 1937, CUA, GB, Min III.7, p. 114; Minute of 5 May 1948, CUA, GB, Box 304, p. 242; Minute of 21 May 1952, CUA, GB, Box 306, p. 220.

${ }^{71}$ Dr Barker, Note of 21 February 1934, CUA, GB, Min III.7, p. 70; Mr Hamson, Minute of 4 May 1949, CUA, GB, Box 305, p. 209; Dr Henderson, Minute of 14 January 1953, CUA, GB, Box 307, p. 88; Miss Cohen, Minute of 21 October 1953, CUA, GB, Box 307, p. 23. ${ }^{72}$ For example, Frederick Charles Bartlett, who was the first Professor of Experimental Psychology at Cambridge (1931-51) and widely regarded as the founder of the subject in Britain, and his successor Oliver Louis Zangwill (1952-81) both visited American centres of psychological research (the former in 1947, the later in 1955). On Bartlett, see Brooke, op. cit. (10), p. 500 and Minute of 23 October 1946, CUA, GB, Box 304, p. 28; on Zangwill, see Minute of 26 January 1955, CUA, GB, Box 308, p. 100.

${ }^{73}$ These travels included the cited trips of Haddon (1914) and Fortune (1951) to Papua and New Guinea, a research leave of Dr Frederick Alexander Kirkpatrick, Reader in Spanish, to 
Buenos Aires for the preparation of a History of Argentina (in 1928), and the two mentioned research stays of economists in Uganda and Australia (both in 1954). On Kirkpatrick, see Minute of 14 March 1928, CUA, GB, Min III.6, p. 37.

${ }^{74}$ Charle, op. cit. (6), p. 423.

${ }^{75}$ Previously, only three research leaves had been granted to natural scientists and these were all spent in the UK. Francis Darwin, Lecturer in Botany, wished to prepare the letters of his father Charles Darwin for publication (Lent term 1887); WFR Weldon, Lecturer in the Advanced Morphology of Invertebrates, aimed to study various species of Decapod Crustacea in the Plymouth Marine Biological Laboratory (academic year 1889/90); and George Nuttall, Professor of Biology, planned to conduct research on the Government Experimental Farm at Wembley, Middlesex (for part of the Easter term 1909). See Minute of 15 November 1886, CUA, GB, Min III.1, p. 128; Minute of 22 October 1888, CUA, GB, Min III.1, p. 178; Minute of 21 October 1889, CUA, GB, Min III.1, p. 205; and Minute of 19 May 1909, CUA, GB, Min III.2, p. 182.

${ }^{76}$ For details, see Dyson, Eddington and Davidson, op. cit. (2).

${ }^{77}$ Minute of 4 May 1921, CUA, GB, Min III.3, p. 153; Minute of 7 November 1921, CUA, GB, Min III.3, p. 165.

${ }^{78}$ Henrika Kuklick and Robert E. Kohler, 'Introduction', in Henrika Kuklick and Robert E. Kohler (eds.), Science in the Field, Osiris (1996) 11, pp. 1-14, p. 4. On local support for scientific travellers, see, for example, Mary L. Pratt Imperial Eyes: Travel Writing and Transculturation, London: Routledge, 1992 and Driver and Jones, op. cit. (26).

${ }^{79}$ Mark Harrison, 'Science and the British Empire', Isis (2005) 96, pp. 56-63, p. 60.

${ }^{80}$ Robert E. Kohler, Landscapes and Labscapes: Exploring the Lab-Field Border in Biology, Chicago: University of Chicago Press, 2002, p. 1.

${ }^{81}$ Kohler, op. cit. (80), pp. 6-7.

${ }^{82}$ Livingstone, op. cit. (7), p. 3.

${ }^{83}$ This includes engineering scientists, who are not discussed in detail in this essay, but whose research travels from Cambridge began even later than in the physical and biological laboratory sciences, namely in the early 1930s (Table 1). 
${ }^{84}$ Denys H. Wilkinson, 'Nuclear Physics at Oxford: Prof. D. H. Wilkinson, F.R.S.', Nature (1957) 180, pp. 464-465.

${ }^{85}$ Minute of 21 April 1954, CUA, GB, Box 307, p. 142.

${ }^{86}$ Note of 30 April 1952, CUA, Notes and agenda for meetings of the General Board, GB 1/6, 9170.

${ }^{87}$ William A. Wooster, 'Personal experiences of a crystallographer', in Paul P. Ewald (ed.) Fifty Years of X-ray Diffraction: Dedicated to the International Union of Crystallography on the Occasion of the Commemoration Meeting in Munich, July 1962, Utrecht: International Union of Crystallography, 1962, p. 682.

${ }^{88}$ Note of 16 October 1935, CUA, GB, Min III.7, p. 90.

${ }^{89}$ Kohler, op. cit. (80), p. 42.

${ }^{90}$ These were the female Demonstrator Dr ME Brown and the male lecturers Dr GS Carter and Dr Cott; see Minute of 19 April 1950, CUA, GB, Box 305, p. 200; Minute of 25 July 1951, GB, Box 306, p. 277; and Minute of 18 April 1951, GB, Box 306, p. 187.

${ }^{91}$ H. Cary Gilson, 'East African Fisheries Research Organization', Nature (1960) 187, pp. $469-470$.

${ }^{92}$ For average durations of research leaves, see note 35.

${ }^{93}$ In the same period, the disciplinary profile of the increasing number of professors remained relatively stable, which shows that the need for travel in the natural and technical sciences had grown above average.

${ }^{94}$ The notion of economic capital is used in Pierre Bourdieu's terms; see Pierre Bourdieu, 'The forms of capital', in J. G. Richardson (ed.) Handbook of Theory and Research for the Sociology of Education, New York: Greenwood Press, 1986, pp. 241-258, p. 253.

${ }^{95}$ Dr Frank Smithies, Lecturer in Mathematics, Minute of 30 January 1952, CUA, GB, Box 306, p. 121.

${ }^{96}$ See Peter Duren (ed.), A Century of Mathematics in America: Part 3, Providence: American Mathematical Society, 1989.

${ }^{97}$ Robin J. Wilson, 'Hardy and Littlewood', in Peter Harman and Simon Mitton (eds.) Cambridge Scientific Minds, Cambridge: Cambridge University Press, 2002, pp. 202-219, p. 202. 
${ }^{98}$ Dirac spent at least the academic years $1934 / 35$ and $1947 / 48$ as well as the Michaelmas term of 1946 in Princeton (the destination of a further stay in the United States during the Michaelmas term of 1931 is undisclosed). In the era of McCarthyism, his scientific contacts in the Soviet Union contributed to the denial of a visa to the United States so that he could not take a further granted leave at the Institute for Advanced Study in the academic year 1954/55. See Helge Kragh, 'Paul Dirac: the purest soul in an atomic age', in Kevin C. Knox and Richard Noakes (eds.), From Newton to Hawking: A History of Cambridge University's Lucasian Professors of Mathematics, Cambridge: Cambridge University Press, 2003, pp. 387-424, p. 414; Minute of 25 February 1931, CUA, GB, Min III.6, p. 118; Minute of 7 March 1934, CUA, GB, Min III.7, p. 71; Minute of 13 March 1946, CUA, GB, Box 303, p. 193; Minute of 19 February 1947, CUA, GB, Box 304, p. 179; Minute of 17 February 1954, CUA, GB, Box 307, p. 112.

${ }^{99}$ Kragh, op. cit. (98), p. 398.

100 This includes not only Princeton but also Copenhagen, where he had protracted discussions with Niels Bohr. See Kragh, op. cit. (98), p. 399.

${ }^{101}$ Heffernan, op. cit. (13).

${ }^{102}$ Charle, op. cit. (6), p. 426. 